\title{
Amicable Settlements of WTO Disputes: Bilateral Solutions in a Multilateral System
}

\author{
WOLFGANG ALSCHNER * \\ Graduate Institute of International and Development Studies (IHEID), Geneva
}

\begin{abstract}
Every third dispute brought to the WTO and not withdrawn early is settled amicably through a mutually agreed solution (MAS). This includes high-profile and long-standing WTO disputes such as EC-Bananas or Softwood Lumber. By offering a negotiated solution to hard cases, MAS have added stability to the multilateral trading system. MAS, however, also raise concerns. Settlements favour the instant resolution of disputes, but may conflict with third party interests and collective stakes. Where WTO members use their MAS to contract out of WTO law ('WTO +'/'WTO-'MAS), the multilateral trading system may be at risk. In addition, new forms of bilateral (interim-)settlements not foreseen in the DSU have recently emerged which currently escape multilateral disciplines. This article assesses how well the DSU balances the competing interests involved in amicable settlements, preserving the contractual flexibility of disputants while safeguarding multilateral interests. Contributing to current DSU reform debates, the article rejects the need for greater MAS enforceability, endorses the strengthening of procedural and substantive safeguards protecting collective stakeholders in settlements, and calls for new DSU disciplines on interim-settlements.
\end{abstract}

\section{Introduction}

According to DSU Article 3.7, an amicable settlement is the outcome 'clearly to be preferred' by the WTO dispute settlement mechanism. Of about 450 cases formally brought before the WTO, over 200 were settled or are presumed to have been settled amicably by the disputing parties in one way or another. ${ }^{1}$ Among the settled disputes are some of the most contentious and well-known WTO cases. In November 2012, a mutually agreed solution (MAS) brought the EC-Bananas dispute between the EU and ten Latin American countries over the former's

\footnotetext{
* Email: wolfgang.alschner@graduateinstitute.ch

I am grateful to Joost Pauwelyn, Manfred Elsig, Babette Ancery and Selina Bruderer for their feedback on earlier versions of this article. I also want to thank Jorge Huerta Goldman for an inspiring conversation on the topic and the editor of the World Trade Review and the two peer-reviewers for their helpful and thought-provoking comments.

1 WTO (2010), Annual Report 2010, Geneva: WTO Secretariat Publication, 82.
} 
discriminatory import regime for bananas from non-ACP countries to an end. ${ }^{2}$ The 'banana war' had preoccupied the GATT and WTO for almost 20 years. Furthermore, already in 2009, the two high-profile SPS cases, EC-Biotech, concerning the EU's market access restrictions on genetically modified agricultural products, and EC-Hormones, relating to the EU's import ban on hormone-treated beef, had, in part, been settled. ${ }^{3}$ These recently resolved disputes highlight the importance of amicable settlements for the WTO, especially as a solution for hard cases where litigation risks becoming endless and compliance is politically impossible.

Yet in spite of their significance, amicable settlements have not attracted much academic attention. Scholars have either focused on particular settlements or limited their analysis to specific legal aspects of MAS, such as their possible enforcement through the WTO dispute settlement mechanism. ${ }^{4}$ A narrow focus on single disputes or MAS enforcement, however, falls short of addressing the many intricate questions amicable settlements of WTO disputes give rise to in law and in practice.

Indeed, amicable settlements are more than private deals struck between disputing parties. Instead, as bilateral solutions in a multilateral system, they point to two potentially competing aspects of justice in WTO dispute resolution. On the one hand, amicable settlements help the disputing parties to find a swift and tailored solution to their dispute. On the other hand, bilateral solutions may be reached at

2 Notification of a Mutually Agreed Solution, European Communities-Regime for the Importation, Sale and Distribution of Bananas (DS16), (DS27), (DS105), (DS158), European Communities - Regime for the Importation of Bananas (DS361), (DS364), European Communities-The ACP-EC Partnership Agreement-Recourse to Arbitration pursuant to the Decision of 14 November 2001 (WT/L/616), European Communities - The ACP-EC Partnership Agreement-Second Recourse to Arbitration pursuant to the Decision of 14 November 2001 (WT/L/625); WT/DS27, WT/DS361, WT/DS364, WT/DS16, WT/ DS105, WT/DS158, WT/L/616, and WT/L/625; 8 November 2012.

3 Joint Communication from the European Communities and the United States, European Communities - Measures Concerning Meat and Meat Products (Hormones), WT/DS26/28, 30 September 2009. Joint Communication from the European Union and Canada, European Communities - Measures Concerning Meat and Meat Products (Hormones), WT/DS48/26, 22 March 2011. As for the case European Communities-Measures Affecting the Approval and Marketing of Biotech Products (ECBiotech), a MAS was reached with Canada (Notification of a Mutually Agreed Solution, WT/DS292/40, 17 July 2009) and Argentina (Notification of a Mutually Agreed Solution, WT/DS293/41, 23 March 2010). The dispute remains unresolved with the US (WT/DS291).

4 On MAS enforcement, see Alberto Alvarez-Jiménez (2011), 'Mutually Agreed Solutions under the WTO Dispute Settlement Understanding: An Analytical Framework after the Softwood Lumber Arbitration', World Trade Review, 10(3): 343-373. For a consultation-based focus of MAS, see Elisa Baroncini (1999), 'The WTO Dispute Settlement Understanding as a Promoter of Transparent, Ruleoriented, Mutually Agreed Solutions - A Study of the Value of DSU Consultations and Their Positive Conclusion', in Paolo Mengozzi (ed.), International Trade Law on the 50th Anniversary of the Multilateral Trading System, Milano, pp. 153-303. For a dispute-based approach, see Leonila Guglya (2011), 'The Interplay of International Dispute Resolution Mechanisms: The Softwood Lumber Controversy', Journal of International Dispute Settlement, 2(1): 175-207. 
the expense of third parties or may undermine collective interests. 'Out-of-court' settlements risk to "work in favor of "private peace" and in opposition to "public justice". 5 This tension was aptly captured in a statement made by John Jackson some 15 years ago. He asked 'what should be the fundamental objective of the [multilateral trading] system - to solve the instant dispute (by conciliation, obfuscation, power-threats, or otherwise), or to promote certain longer term systemic goals such as predictability and stability of interpretations of treaty text?'6 Nowhere in the WTO's dispute settlement system is the balancing of these potentially competing objectives more acute than with respect to negotiated settlements. Multilateral considerations and 'longer term systemic goals' may generally be absent when it comes to deals struck between two disputing states where bilateral interests and the goal of solving 'the instant dispute' are paramount. As a result, one must ask whether the WTO regulates amicable settlements in a way that preserves their benefits for complainants while advancing and protecting the multilateral stakes of the WTO system.

This analysis needs to take place against the backdrop of the actual settlement practice of WTO members where two trends have emerged. First, similar to the better-known practice of concluding preferential trade agreements (PTAs) in deviation of WTO disciplines, ${ }^{7}$ WTO members have used MAS to contract out of WTO law ('WTO-' MAS) or to add to WTO obligations ('WTO+' MAS). In the Softwood Lumber MAS between Canada and the United States, for instance, both parties waived their right to initiate WTO proceedings ('WTO-') and agreed on specific disciplines and institutional mechanisms ('WTO+') to govern their bilateral softwood lumber trade. ${ }^{8}$ Although this practice demonstrates that MAS confer much needed flexibility on disputants when dealing with hard or multijurisdictional cases, such contracting-out may conflict with larger WTO systemic goals. So where does the WTO draw the line between legal and illegal MAS?

Second, in recent years, WTO members have added a further layer of complexity. Instead of signing MAS as the category of amicable settlements that the DSU explicitly recognizes, encourages, and regulates in paragraphs 5 to 7 of Article 3,

5 Carrie Menkel-Meadow (1995), 'Whose Dispute Is It Anyway?: A Philosophical and Democratic Defence of Settlement (in Some Cases)', Georgetown Law Journal, 83: 2663-2696, at 2667. On the domestic side of the settlements debate, see also Owen M. Fiss (1984), 'Against Settlements', Yale Law Journal, 93: 1073-1090 and David Luban (1995), 'Settlements and the Erosion of the Public Realm', Georgetown Law Journal, 83: 2619-2662.

6 John H. Jackson (1998), 'Dispute Settlement and the WTO: Emerging Problems', Journal of International Economic Law, 1(3): 329-351, at 331 (emphasis added).

7 Gabrielle Marceau (2009), 'News from Geneva on RTAs and WTO-plus, WTO-more, and WTOminus', Proceedings of the Annual Meeting American Society of International Law, 103: 25-28 March 2009, 124-128.

8 Notification of Mutually Agreed Solution, United States-Reviews of Countervailing Duty on Softwood Lumber from Canada (US-Softwood Lumber), WT/DS311/2, 16 November 2006. 
WTO members have concluded interim-settlements not foreseen in the DSU. These agreements typically outline compliance steps towards a final solution of the dispute, and pledge notification as a MAS at a later stage. In 2010, for example, a 'Framework for a Mutually Agreed Solution' was negotiated in the US-Upland Cotton dispute. ${ }^{9}$ Similarly, in early 2012, a Memorandum of Understanding (MoU) was reached to end the US-Zeroing cases. ${ }^{10}$ The rise of these interimsettlements is accompanied by an overall decrease in the number of WTO disputes settled through MAS in recent years (see section 2 below).

In light of these trends and the competing interests involved in settlements, this article provides an in-depth discussion of the procedural and substantive regulation of amicable settlements in the WTO. It finds that the DSU and Appellate Body jurisprudence have so far succeeded fairly well in preserving the contractual flexibility of disputants while also safeguarding the interests of other WTO stakeholders. There is room for improvement though. While calls for an automatic MAS enforcement made in the context of DSU reform debates are unwarranted, other DSU amendments should be made to increase clarity and promptness in MAS notification. Furthermore, the system needs urgent improvement when it comes to integrating the new practice of interim-settlement into DSU structures as part of a newly proposed two stage settlement procedure.

After this introduction, section 2 provides an overview of the law and practice of amicable settlements in the WTO, exposing recent settlement trends. Section 3 identifies the competing judicial policy considerations raised in settlements and develops a framework for subsequent analysis. Building on these benchmarks, the remainder of the article evaluates how well the DSU preserves the advantages of settlements and mitigates their drawbacks. Section 4 traces the historical evolution of amicable settlements of trade disputes from a purely diplomatic tool to a more circumscribed and regulated element of the multilateral trading system. Section 5 discusses the conceptual and practical challenges of defining and managing settlements in a hybrid system such as the DSU that combines consensual and adjudicatory elements. Section 6 forms the centrepiece of the study providing an analysis of the regulation of MAS in DSU Articles 3.5-7 and jurisprudence. Building on these findings, section 7 concludes on an evaluation of current DSU reform efforts with respect to settlements.

9 Joint Communication from Brazil and the United States, United States - Subsidies on Upland Cotton, WT/DS267/45, 31 August 2010.

10 Joint Communication from the United States and Japan, United States-Measures Relating to Zeroing and Sunset Reviews, WT/DS322/44, 8 February 2012. Joint Communication from the European Communities and the United States, United States - Laws, Regulations and Methodology for Calculating Dumping Margins ('Zeroing'), WT/DS294/43, and United States - Continued Existence and Application of Zeroing Methodology, WT/DS350/20, 8 February 2012. 


\section{MAS - an overview of law and practice}

\subsection{MAS and the DSU}

Since the inception of the GATT, two competing views on how to solve trade disputes have occupied diplomats and academics alike. Some argue that disputes are best settled through negotiation and compromise; not legal principles and lawyers, but economic policy and diplomats should be the driving forces in the dispute settlement procedure. Others have advanced the opposite view, arguing for a more judicial and legalistic settlement of disputes involving a neutral third-party adjudicator. ${ }^{11}$

Today's DSU, as John Jackson observed, contains elements of both views. ${ }^{12}$ It provides a right to adjudication to complainants, quasi automaticity in the adoption of panel reports, and the possibility of appeal on matters of law. On the other hand, the DSU mandates consultations, preserves a preference for mutually agreed settlements of disputes, and requires panels to facilitate settlements between the parties. Hence, the resolution of disputes occurs today through a hybrid system combining diplomatic and adjudicatory elements.

In this hybrid system, amicable solutions of WTO disputes are explicitly regulated. DSU Article 1.1 states that the Agreement also applies to 'consultations and the settlement of disputes between Members'. The aim of the DSU is to 'secure a positive solution to a dispute' pursuant to Article 3.7. That same Article envisages four different remedies. Mutually agreed solutions by the parties to a dispute that are consistent with the WTO agreements are the preferred remedy. Only if no such solution can be reached, the primary goal becomes the withdrawal of the inconsistent measures. In case of non-compliance, members may have access to the two remedies of last resort: temporary compensation and the suspension of concessions. Hence, the DSU establishes a clear hierarchy of remedies in which consensual dispute resolution trumps adjudication.

The preference for MAS is reflected throughout the stages of the DSU. Article 4.3 clarifies that the aim of consultations - the first step of the WTO dispute settlement procedure - is to reach a mutually satisfactory solution to a dispute. When consultations fail and a panel is established, the panel should give the parties 'adequate opportunity to develop a mutually satisfactory solution' in accordance with DSU Article 11. Only if parties do not arrive at a MAS, a panel shall submit its legal findings to the Dispute Settlement Body (DSB) for adoption pursuant to Article 12.7. Taken together with DSU Article 15, which allows parties to review and comment on a panel report before it is circulated among members, these provisions

11 John H. Jackson (1998), 'Dispute Settlement in the WTO: Policy and Jurisprudential Considerations', School of Public Policy, University of Michigan, Discussion Paper, No. 419, at 2-3. See also Robert E. Hudec (1980), 'GATT Dispute Settlement after the Tokyo Round: An Unfinished Business', Cornell International Law Journal, 13: 145-204, at 151-153.

12 Jackson, 'Dispute Settlement in the WTO', supra n. 6, at 15, 22. 
enable members to forego a DSB ruling, by reaching a MAS, until the very last minute of the panel process. ${ }^{13}$ Finally, also during the compliance phase, a solution agreed upon by the parties to the dispute can either prevent retaliation altogether as per Article 22.2 or end the suspension of concessions in accordance with Article 22.8. In sum, MAS are available to disputing parties throughout the stages of the WTO dispute settlement procedure.

To align the preference for bilateral settlements with the overall multilateral nature of the WTO system, MAS are conditioned by two obligations, which the Panel in EC-Bananas III (Article 21.5-Ecuador) called MAS' 'multilateral elements' ${ }^{14}$ First, DSU Article $3.5^{15}$ mandates that settlements between the disputing parties, like any other solution to disputes raised under the DSU, have to be consistent with the WTO covered agreements and shall neither nullify or impair benefits, nor frustrate any objective arising from these agreements. Second, MAS have to be notified in compliance with DSU Article $3.6^{16}$ to all relevant WTO bodies where other members can raise any point of concern.

\subsection{MAS in practice}

About every third WTO dispute that is not withdrawn early ends with a formally notified MAS. ${ }^{17}$ Until December 2012, WTO members formally notified 80 MAS. ${ }^{18}$ Of these settlements, $49 \%$ had been reached at the consultation stage, $22 \%$ during panel proceedings, and $29 \%$ in the course of the compliance phase.

13 See also Armin Steinbach (2009), 'The DSU Interim Review - Need for Its Elimination or Extension to the Appellate Body Stage', Journal of International Economic Law, 12(2): 417-434.

14 Panel Report, European Communities-Regime for the Importation, Sale and Distribution of Bananas-Recourse to Article 21.5 of the DSU by Ecuador (EC-Bananas III (Article 21.5-Ecuador)), WT/DS27/RW/ECU, adopted 6 May 1999, para. 7.102.

15 DSU Article 3.5: 'All solutions to matters formally raised under the consultation and dispute settlement provisions of the covered agreements, including arbitration awards, shall be consistent with those agreements and shall not nullify or impair benefits accruing to any Member under those agreements, nor impede the attainment of any objective of those agreements.' The same requirement of consistency is repeated in DSU Article 3.7.

16 DSU Article 3.6: 'Mutually agreed solutions to matters formally raised under the consultation and dispute settlement provisions of the covered agreements shall be notified to the DSB and the relevant Councils and Committees, where any Member may raise any point relating thereto.'

17 Miguel Burnier da Silveira, Andreas Sennekamp, and Werner Zdouc (2010), 'Die Bedeutung der konsensualen Elemente des WTO-Streitbeilegungsverfahrens in der Lösung internationaler Handelskonflikte', in Universität Graz, Konfliktlösung im Konsens, Schiedsgerichtsbarkeit, Diversion, Mediation, Tagungsband zum 7, Fakultätstag, Graz, 28-50, at 34. More cases are presumed to have been settled, in which no formal MAS notification occurred. See Kara M. Reynolds (2007), 'Why Are So Many WTO Disputes Abandoned?', American University Washington DC, Department of Economics Working Paper Series, No. 2007-05.

18 This number is the result of a careful review of the individual dispute settlement records available at www.wto.org/english/tratop_e/dispu_e/dispu_status_e.htm. Multi-dispute settlements are counted as sum of the individually filed disputes involved. MAS not formally notified and not included in the records of individual disputes are not counted, even if their existence may be discerned based on minutes from DSB meetings. Hence, the number of actual (including not notified) MAS will thus be higher. Because of the 
MAS occur across the entire range of WTO disputes. They resolve cases over trade in goods, services, and intellectual property rights. Furthermore, both developing and developed countries engage in MAS. Some MAS, such as the Softwood Lumber Agreement, take the form of binding international agreements. ${ }^{19}$ Other settlements are limited to a simple letter exchange indicating a compromise. ${ }^{20}$ Often, the notification of a MAS includes references to a piece of domestic legislation that brought an allegedly inconsistent measure into WTO conformity, e.g. by amending a discriminatory tariff schedule. ${ }^{21}$ In other instances, parties agree on transition periods and gradual implementation measures. ${ }^{22}$ Certain MAS, as in the Softwood Lumber litigation, end multiple WTO cases over a similar matter involving the same disputants. ${ }^{23}$ Other settlements, as in the India-Quantitative Restrictions disputes, comprise one MAS relating to complaints by different members over the same measure. ${ }^{24}$ Interestingly, such multi-party MAS, usually signed simultaneously and having the same content, constitute roughly half of all disputes resolved through MAS. In addition, certain MAS involve settlements between only some but not all of the claimants. ${ }^{25}$ Finally, MAS sometimes link different levels of trade governance. The 2006 settlement of the Softwood Lumber

methodology used this number may diverge from other counts, e.g. from that of Burnier da Silveira et al., Die Bedeutung der konsensualen Elemente, supra n. 17. MAS formally notified under Article 3.6 until September 2011 are also listed in the WTO Analytical Index under DSU Article 3.6 amounting to 66 MAS, see www.wto.org/english/res_e/booksp_e/analytic_index_e/dsu_01_e.htm\#article3B5. This (in contrast to our count) does not include several MAS concluded at the implementation stage, e.g. the Communication from Japan and the United States, Japan-Measures Affecting Agricultural Products, WT/DS76/12, 30 August 2001.

19 Notification of Mutually Agreed Solution, United States-Reviews of Countervailing Duty on Softwood Lumber from Canada (US-Softwood Lumber), WT/DS311/2, 16 November 2006.

20 For examples, see Baroncini, 'The WTO Dispute Settlement Understanding', supra n. 4, at 252-254. Alvarez-Jiménez, 'Mutually Agreed Solutions', supra n. 4, at 348.

21 For instance, Notification of Mutually Agreed Solution, Panama-Tariff Classification of Certain Milk Products, WT/DS329/2, 6 October 2005.

22 For instance, Notification of Mutually Agreed Solution, United States-Measures Affecting Textiles and Apparel Products (II), WT/DS151/10, 31 July 2000.

23 The Softwood Lumber dispute involved six WTO cases. See Notification of Mutually Agreed Solution, United States - Reviews of Countervailing Duty on Softwood Lumber from Canada, WT/DS311/ 2, 16 November 2006. For detailed discussion, see Leonila Guglya (2011), 'The Interplay of International Dispute Resolution Mechanisms: The Softwood Lumber Controversy', Journal of International Dispute Settlement, 2(1): 175-207.

24 For instance, in the case India-Quantitative Restrictions on Imports of Agricultural, Textile and Industrial Products (India-Quantitative Restrictions), the complainants by Australia (WT/DS91), Canada (WT/DS92), the EC (WT/DS96), New Zealand (WT/DS93), Switzerland (WT/DS94), and the US (WT/ DS90) were settled in a MAS see Notification of Mutually Agreed Solution Addendum, India-Quantitative Restrictions, WT/DS90/2/Add.1, WT/DS91/2/Add.1, WT/DS92/2/Add.1, WT/DS93/2/Add.1, WT/DS94/ 2/Add.1, WT/DS96/2/Add.1, 14 January 1999. It is noteworthy that this happened although the consultation requests were slightly different. Switzerland, for instance, did not claim a violation of the Agreement on Agriculture.

25 For example, the European Communities-Measures Affecting the Approval and Marketing of Biotech Products (EC-Biotech) case involved three complainants: the US (WT/DS/291), Canada (WT/DS/ 292), and Argentina (WT/DS/291). While a MAS was reached with Canada (Notification of a Mutually 
dispute involving Canada and the US included a Termination of Litigation Agreement that settled 20 national, NAFTA, and WTO proceedings. ${ }^{26}$

\subsection{Recent settlement trends: the rise of interim-settlements}

When looking at the settlement practice of WTO members over time, two trends become visible. First, the number of notified MAS has decreased in recent years. While in 1998 the number of MAS peaked with 15 settlements notified, this number dropped to zero in 2011. The sudden surge in 2012 is due to the EC-Bananas MAS, which settled six WTO disputes. It remains to be seen whether this points to a reversal of the downward trend.(figure 1)

Second, members are instead concluding new forms of (interim-)settlements not foreseen in the DSU. These include Memoranda of Understanding, which envisage steps towards a final settlement that is then to be notified as MAS pursuant to DSU Article 3.6. In addition, other forms of sui-generis settlements have emerged which also typically contain a pledge of future Article 3.6 notification. They involve high-profile cases such as the 'Framework for a Mutually Agreed Solution' in the US-Upland Cotton dispute ${ }^{27}$ and the 2009 'Geneva Agreement on Bananas'28 preceding the 2012 Bananas MAS. Over the last five years, ten MoUs and three other sui-generis settlements have been concluded (see table 1). In other words, recently WTO members have de facto introduced the new category of interimsettlements into the WTO dispute settlement process.

\section{Regulating settlements: a balancing exercise}

Bilateral settlements in a multilateral context raise intricate judicial policy considerations that require balancing. On the one hand, amicable settlements can restore 'peace' between the disputing parties. On the other hand, collective values should not be upset or third parties' rights impaired by the dispute's resolution. To fully appreciate how the DSU does or does not achieve this balance, it is useful to divide the trade-offs associated with amicable settlements of WTO disputes into three categories, which will be briefly discussed in turn. The first category comprises the risks and opportunities of settlements for the disputing parties. The second and third categories refer to settlements' procedural and substantive tradeoffs between the disputants and collective stakeholders affected by the WTO

Agreed Solution, WT/DS292/40, 17 July 2009) and Argentina (Notification of a Mutually Agreed Solution, WT/DS293/41, 23 March 2010), the dispute remains unresolved with the US.

26 Notification of Mutually Agreed Solution, US-Softwood Lumber, supra n. 8, at Annex 2A.

27 Joint Communication from Brazil and the United States, United States-Subsidies on Upland Cotton, WT/DS267/45, 31 August 2010.

28 Communication from Brazil, Colombia, Costa Rica, Ecuador, European Union, Guatemala, Honduras, Mexico, Nicaragua, Panama, Peru, and the Bolivarian Republic of Venezuela, Geneva Agreement on Bananas, WT/L/784, 15 December 2009. 
Figure 1. MAS and interim-settlements based on their year of notification to the WTO

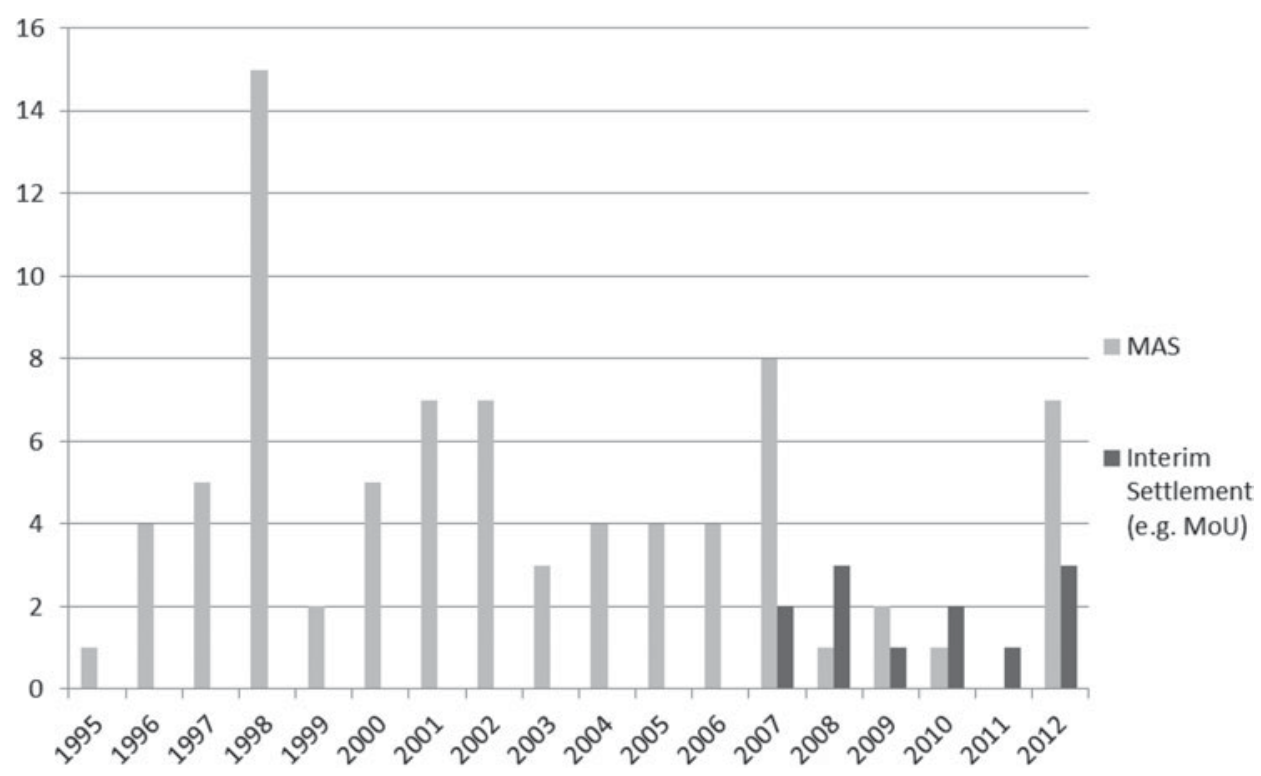

dispute settlement process, namely domestic traders and consumers, third WTO members, and the WTO system at large.

\subsection{MAS and the disputing parties}

MAS $^{29}$ promise several benefits to disputing parties. First, settlements help the disputants to avoid unnecessary costs and delays in litigation. This is particularly important in the WTO which only provides for prospective remedies but not damages for past harm. ${ }^{30}$ Second, they allow WTO members to retain control over the dispute settlement process and its outcome. Settlement negotiations can broaden the issues under consideration opening the door for horse-trading and side-payments, impossible under normal panel proceedings.

MAS also involve risks for the disputants. Settlement negotiations may become subject to power asymmetries with powerful members bullying smaller countries

29 For the purpose of this section, we use the term MAS to refer to amicable settlements of WTO disputes. For a more detailed appreciation of the definition of MAS and its relationship to other negotiated agreements such as MoUs, see section 5 below.

30 Exporters thus have an incentive to push their governments into an early settlement to resume normal trading. See Amelia Porges (2003), 'Settling WTO Disputes: What Do Litigation Models Tell Us?', Ohio State Journal on Dispute Resolution, 19(1): 141-184, at 145. 
Table 1. Interim-settlements

\begin{tabular}{|c|c|c|c|c|c|}
\hline Dispute number & Claimant & Respondent & Case name & $\begin{array}{l}\text { Year of } \\
\text { notification }\end{array}$ & $\begin{array}{l}\text { Document } \\
\text { number }\end{array}$ \\
\hline \multicolumn{6}{|c|}{ Memorandum of Understanding } \\
\hline 26 & US & $\mathrm{EC}$ & Measures Concerning Meat and Meat Products (Hormones) & 2009 & WT/DS26/29 \\
\hline 48 & Canada & EC & Measures Concerning Meat and Meat Products (Hormones) & 2011 & WT/DS48/26 \\
\hline 294 & $\mathrm{EC}$ & US & $\begin{array}{l}\text { United States-Laws, Regulations and Methodology for } \\
\text { Calculating Dumping Margins (Zeroing) }\end{array}$ & 2012 & WT/DS294/43 \\
\hline 322 & Japan & US & United States-Measures Relating to Zeroing and Sunset Reviews & 2012 & WT/DS322/44 \\
\hline 350 & $\mathrm{EC}$ & US & $\begin{array}{l}\text { United States-Continued Existence and Application of Zeroing } \\
\text { Methodology }\end{array}$ & 2012 & WT/DS350/20 \\
\hline 358 & US & China & $\begin{array}{l}\text { Certain Measures Granting Refunds, Reductions or Exemptions } \\
\text { from Taxes and Other Payments }\end{array}$ & 2007 & WT/DS358/14 \\
\hline 359 & Mexico & China & $\begin{array}{l}\text { Certain Measures Granting Refunds, Reductions or Exemptions } \\
\text { from Taxes and Other Payments }\end{array}$ & 2007 & WT/DS359/14 \\
\hline 372 & $\mathrm{EC}$ & China & $\begin{array}{l}\text { Measures Affecting Financial Information Services and Foreign } \\
\text { Financial Information Suppliers }\end{array}$ & 2008 & WT/DS372/4 \\
\hline 373 & US & China & $\begin{array}{l}\text { Measures Affecting Financial Information Services and Foreign } \\
\text { Financial Information Suppliers }\end{array}$ & 2008 & WT/DS373/4 \\
\hline 378 & Canada & China & $\begin{array}{l}\text { Measures Affecting Financial Information Services and Foreign } \\
\text { Financial Information Suppliers }\end{array}$ & 2008 & WT/DS378/3 \\
\hline \multicolumn{6}{|c|}{ Sui generis settlements } \\
\hline 27 & $\begin{array}{l}\text { Ecuador; Guatemala; } \\
\text { Honduras; Mexico; US }\end{array}$ & EC & Regime for the Importation, Sale and Distribution of Bananas & 2009 & WT/L/784 \\
\hline 193 & EC & Chile & Measures affecting the Transit and Importing of Swordfish & 2010 & WT/DS193/4 \\
\hline 267 & Brazil & US & Subsidies on Upland Cotton & 2010 & WT/DS267/45 \\
\hline
\end{tabular}


into signing a MAS. ${ }^{31}$ The DSU's adjudicatory elements alleviate some of these inequalities, casting a 'shadow of the law' over settlement negotiations. ${ }^{32}$ However, powerful countries still possess means outside of the WTO to buy off or deter their smaller negotiating partner. In a case study, Shanker concluded that 'Argentina appears to have been coerced into agreeing to amend its use of anti-competition provisions in its patent acts' 33 in a 2002 US-Argentina MAS. ${ }^{34}$ The United States supposedly asserted pressure bilaterally and through the IMF, taking advantage of the Argentinean economic crisis in the early 2000s in order to 'dictate a series of changes in Argentina's Patent Acts through "Mutually Agreed Solution"'.35 A second concern for the disputants relates to compliance with and enforcement of MAS. Baroncini's review of early MAS practice finds multiple instances of parties to MAS complaining about divergent interpretations and unsatisfactory implementation. ${ }^{36}$ Moreover, alleged non-compliance with the terms of a MAS was raised in two complaints brought to WTO panels (see section 6). Hence, power asymmetries and enforcement problems are the main pre-occupation of disputants in MAS.

\subsection{Procedural balancing: transparency versus confidentiality}

Aside from balancing competing interests of the disputants, MAS also raise important trade-offs between the interests of collective stakeholders and those of the disputants. Procedurally, disputants may find it necessary to keep their negotiations confidential in order to resolve delicate and politically controversial disputes. DSU Article 4.6 recognizes the need for negotiations behind closed doors, mandating consultations to remain confidential.

The requirement of confidentiality, however, may conflict with the interests of other stakeholders in transparency of bilateral settlements. First, domestic stakeholders may bear the costs of settlements that escape their democratic control. According to Petersmann, the WTO serves an important constitutional function by protecting economic liberties and individual consumer rights from protectionist

31 Johan Lindeque and Steven McGuire (2007), 'The United States and Trade Disputes in the World Trade Organization: Hegemony Constrained or Confirmed?', Management International Review, 47(5): 725-744, at 729, 734-735.

32 Marc Busch and Eric Reinhardt (2000), 'Bargaining in the Shadow of the Law: Early Settlement in GATT/WTO Disputes', Fordham International Law Journal, 24(1): 158-172. John H. Jackson (1997), The World Trading System: Law and Policy of International Economic Relations, 2nd edn, MIT Press, at 109-110.

33 Daya Shanker (2004), 'Argentina-US Mutually Agreed Solution, Economic Crisis in Argentina and Failure of the WTO Dispute Settlement System', Idea: Journal of Law and Technology, 44(4): 565-615, at 571.

34 Notification of Mutually Agreed Solution According to the Conditions Set Forth in the Agreement, Argentina-Certain Measures on the Protection of Patents and Test Data, WT/DS171/3, WT/DS196/4, 20 June 2002.

35 Shanker, 'Argentina-US Mutually Agreed Solution', supra n. 33, at 566.

36 Baroncini, 'The WTO Dispute Settlement Understanding', supra n. 4, at 260-275. 
tendencies in their government. ${ }^{37}$ For democratic checks and balances to work, domestic stakeholders require access to information, including those relating to bilateral settlements. Second, other WTO members equally want MAS to be transparent. By not disclosing the terms of a settlement, disputants may prevent other WTO members from claiming most-favoured-nation (MFN) advantages arising out of a settlement. Moreover, other WTO members have an interest in scrutinizing MAS to ensure that such settlements are not struck at their expense more generally. Third, MAS also affect the multilateral trading system as a whole. Panel and Appellate Body reports provide an important public good function safeguarding security and predictability of trade rules and reinforcing trade expectations. Settlements, when kept private and confidential, fail to further other members' understanding of states' trade-related behaviour. If they are made public, however, they can generate positive externalities not unlike findings by adjudicators, providing guidance on how hard cases can be solved amicably. Therefore, transparency of settlements is a stake common to domestic consumers and traders, third parties, as well as the system at large.

\subsection{Substantive balancing: flexibility versus WTO consistency}

Substantively, MAS offer additional flexibility to disputants which may potentially be detrimental to other stakeholders, particularly if compared to an outcome reached through adjudication. WTO panels and the Appellate Body aim to preserve the overall balance of trade concessions with a view to safeguarding not only the interests of the disputants but of the WTO membership as a whole. Accordingly, recommendations by the DSB 'cannot add to or diminish the rights and obligations in the covered agreements' pursuant to DSU Article 3.2. While some settlements produce an outcome effectively identical to what would have been reached through adjudications, other MAS do what WTO adjudicators cannot do: adding to or diminishing rights and obligations.

Disputants may reach 'WTO-' settlements that are more limited in scope than a potential panel report leaving possible violations unaddressed or waiving rights conferred by the covered agreements. In 'WTO-' MAS, disputants effectively contract out of WTO law. In some MAS, for instance, disputants waived their right to initiate further DSU proceedings. ${ }^{38}$ Disputants may also agree on 'WTO+'

37 Ernst-Ulrich Petersmann (2002), 'Constitutionalism and WTO Law: From a State-centered Approach towards a Human Rights Approach in International Economic Law', in Kennedy and Southwick (eds.) (2002), The Political Economy of International Trade Law: Essays in Honor of Robert Hudec, Cambridge: Cambridge University Press, pp. 32-67. Also producers see their risk premium decrease and profit margins increase in a more stable and predictable world trading system, see Jackson, 'Dispute Settlement and the WTO', supra 6, at 17.

38 For instance, in the case Chile-Measures Affecting the Transit and Importation of Swordfish. 'In addition, Chile and the European Union hereby notify the Dispute Settlement Body and the Council for Trade in Goods that they have unconditionally agreed that neither party shall further exercise any procedural right accruing to it under the DSU in case DS193 Chile-Measures Affecting the Transit and 
settlements that could be more comprehensive than panel reports. This may take the form of additional rights, commitments, and side-payments. For instance in the EC-Biotech case, the EU concluded a Memorandum of Understanding with Argentina and Canada respectively, setting up a bilateral dialog on biotechnology in agriculture. ${ }^{39}$ Another example is the 'Trade in Cement Agreement' between Mexico and the US which aside from solving a WTO dispute over US anti-dumping measures on cement from Mexico also settled NAFTA panel proceedings and comprehensively addressed the trade in cement between the two countries. ${ }^{40}$

These 'WTO-/WTO +' MAS may be problematic when it comes to the interests of other stakeholders. In settlements, disputants have an incentive to internalize the benefits of settlements, but to externalize their costs. ${ }^{41}$ Disputants may thus strike private deals at the expense of other stakeholders. For instance, in a dispute over Japan's import quota on laver (seaweed), which, among other things, is used to prepare sushi, South Korea agreed to a MAS in which Japan promised to allocate its annual import quota exclusively to Korean laver products. ${ }^{42}$ The WTO consistency of the settlement has been called 'dubious'. ${ }^{43}$ The DSU thus needs to protect the interests of domestic stakeholders, third parties, and the WTO membership at large by limiting the contractual freedom of disputants in MAS. Additionally, other WTO members may need to be able to react if their rights are indeed threatened. This raises the question of whether MAS can be challenged, e.g. before a panel, if they do conflict with third party rights.

\subsection{Conclusion: a framework for analysis}

In sum, MAS raise balancing considerations in at least two ways. First, between the disputants - the benefits and drawbacks of settlements need to be balanced out. While they hope for a prompt, cost-saving, and need-based settlement, claimant and respondent are concerned with power asymmetries and enforcement questions in settlements. Second, the interests between disputants and collective stakeholders require balancing, since MAS work primarily towards 'instant dispute resolution' and not 'systemic goals'. Procedurally, disputants may favour confidential settlements, whereas other stakeholders ask for transparency. Substantively, disputants

\footnotetext{
Importation of Swordfish.' Chile-Measures Affecting the Transit and Importation of Swordfish-Joint Communication from the European Union and Chile - Addendum, WT/DS193/4, 3 June 2010.

39 European Communities - Measures Affecting the Approval and Marketing of Biotech Products Notification of a Mutually Agreed Solution (Canada), WT/DS292/40, 17 July 2009 and Notification of a Mutually Agreed Solution (Argentina), WT/DS293/41, 23 March 2010.

40 Notification of Mutually Agreed Solution, US - Anti-Dumping Measures on Cement from Mexico, WT/DS281/8, 21 May 2007.

41 Luban, 'Settlements and the Erosion of the Public Realm', supra n. 5, at 2626, 2652-2653.

42 Notification of Mutually Agreed Solution, Japan-Import Quotas on Dried Laver and Seasoned Laver, WT/DS323/5, 27 January 2006.

43 Junji Nakagawa (2007), 'No More Negotiated Deals?: Settlement of Trade and Investment Disputes in East Asia', Journal of International Economic Law, 10(4): 837-867, at 856-858.
} 
Figure 2. Stakes, stakeholders and balancing considerations in WTO settlements
Instant Dispute Resolution/ Private Peace

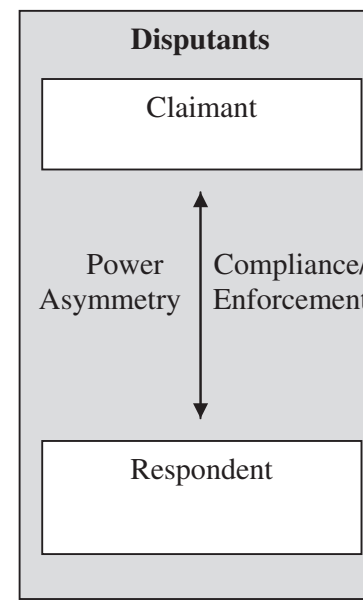

vs

Systemic Goals/

Public Justice

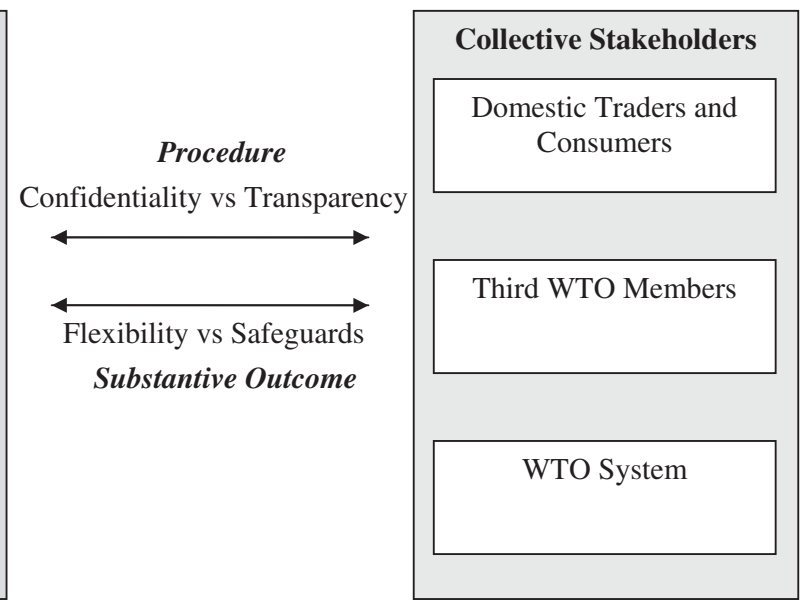

value flexibility in settlement outcomes. In contrast, third parties and the system at large have an interest in constraining this flexibility to harmonize MAS with collective stakes (figure 2). In the remainder of this article, we will use this framework to determine how successful the WTO balances competing interests in settlements looking at the system's evolution (section 4), the definition of MAS (section 5), and the procedural and substantive regulation of MAS in DSU Articles 3.5-7 (section 6).

\section{The history of regulating MAS}

How a dispute settlement system balances the competing interests involved in amicable settlements depends on that system's overarching design and objectives. In the context of international trade, amicable settlements have been subject to increasing regulation and multilateral controls as a result of the trading system's evolution. From GATT's inception in 1947 to the creation of the WTO in 1994, the international trading system underwent a gradual 'legalization'. ${ }^{44}$ It developed from a 'power-oriented' to a 'rule-oriented' diplomacy. ${ }^{45}$ In the course of this transformation, the dispute settlement mechanism became increasingly adjudicatory

44 Judith Goldstein and Lisa L. Martin (2000), 'Legalization, Trade Liberalization, and Domestic Politics: A Cautionary Note', International Organization, 54(3): 603-632, at 604-605.

45 Jackson, The World Trading System, supra n. 32, at 109-111. 
without, however, altogether losing its diplomatic elements. The increasing regulation of MAS through multilateral safeguards is an epitome of this broader evolution.

The early GATT 1947 dispute settlement procedure was based on GATT Articles XXII and XXIII. Article XXII foresees consultations aiming to 'find a satisfactory solution' to the dispute. If the parties failed to reach a bilateral solution, the matter was referred to the GATT contracting parties for collective deliberation. ${ }^{46}$ Hence, in contrast to today's adjudicatory elements, 'GATT's enforcement mechanism (Article XXIII) was a diplomatic procedure'. ${ }^{47}$ In other words, if bilateral negotiation failed, multilateral settlement talks took over with a view to maintaining a balance of concessions.

In the years following GATT's inception, the dispute resolution process underwent a gradual legalization. The procedure 'transformed from a purely diplomatic exercise to a modified form of third-party adjudication'. ${ }^{48}$ It was in this context during the Tokyo Negotiation Round, that the contracting parties adopted the Understanding Regarding Notification, Consultation, Dispute Settlement and Surveillance in 1979.49 The document claims to codify GATT's 'customary practice' of dispute settlement and adds new elements and clarifications. References to MAS appear in the document multiple times. ${ }^{50}$ In many parts, the 1979 Understanding forms the basis on which the DSU was later negotiated. For instance, Annex Article 4 relating to the codified practice contains the familiar passage: 'The aim of the Contracting Parties has always been to secure a positive solution to a dispute. A solution mutually acceptable to the parties to a dispute is clearly to be preferred.' ${ }^{51}$ Compared to today's almost identical DSU Article 3.7, it should be noted that the qualification 'consistent with the covered agreements' is still absent. This insertion was only made in the later stages of the Uruguay Negotiations. ${ }^{52}$

While the document refers to the central role of MAS as GATT customary practice, the 1979 Understanding, in fact, 're-invents' GATT history, making amicable settlements appear to be the primary objective throughout all stages of the dispute settlement process. ${ }^{53}$ Hudec calls the 1979 Understanding a 'rather artful

46 GATT Article XXIII:2.

47 Joost Pauwelyn (2005), 'The Transformation of World Trade', Michigan Law Review, 104(1): 1-65, at 14 .

48 Ibid., at 20.

49 Understanding regarding Notification, Consultation, Dispute Settlement and Surveillance, L/4907, 28 November 1979.

50 Ibid., Article 18, and Annex Articles 3, 4, and 6.

51 Ibid., Annex Article 4.

52 The reference is found in so called 'Dunkel Draft' in Article 1.7 of the DSU Draft text: 'A solution mutually acceptable to the parties to a dispute and consistent with the General Agreement is clearly to be preferred' (emphasis added), Uruguay Round-Draft Final Act Embodying the Results of the Uruguay Round of Multilateral Trade Negotiations, MTN.TNC/W/FA, 20 December 1991, S.2.

53 Robert E. Hudec (1980), 'GATT Dispute Settlement after the Tokyo Round: An Unfinished Business', Cornell International Law Journal, 13: 145-204, at 186. 
revision of GATT history' and adds that the 'documents are not, however, meant to be historical essays. They are statements of current regulatory policy.' 54 In fact, the emphasis placed on reaching a MAS, including at the adjudication stage, was a response to pressing and specific concerns among GATT members about 'wrong cases' being brought before GATT panels. 'Wrong cases' referred to disputes irresolvable through adjudication, because highly sensitive domestic political or economic interests were at stake that would prevent governments from complying with a panel ruling. ${ }^{55} \mathrm{~A}$ widespread practice of non-compliance, it was feared, would undermine the system's prestige and functionality. ${ }^{56}$ Since, at the same time, the GATT contracting parties sought to strengthen access and efficacy of the dispute settlement system, the emphasis placed on MAS also during panel proceedings was perceived as a way to solve the 'wrong case' problem through more negotiation in dispute settlement without foregoing greater legalization elsewhere. ${ }^{57}$ In short, the explicit preference for MAS throughout the dispute settlement stages was not a remnant from early GATT diplomacy-only-days or subsequent practice, but a solution to a concrete problem facing trade policy makers in the Tokyo Round and was introduced together with greater legalization.

Elements protecting the interests of third stakeholders in settlements are still largely absent in the 1979 Understanding. Only Article 19 contains a collective safeguard:

if a mutually satisfactory solution is developed by the parties to a dispute before a panel, any contracting party with an interest in the matter has a right to enquire about and be given appropriate information about that solution in so far as it relates to trade matters.

While this insertion is a first effort to put in place a transparency mechanism that allows third countries to verify that a dispute is not settled at their expense, it remains limited in scope. First, the Article refers only to a MAS developed 'before a Panel'. Bilateral settlements concluded at the consultation stage thus remain outside of the scope of the provision. Second, the right to receive information is restricted to 'trade matters'. It hence excludes information on non-trade side-payments.

It was only with the Uruguay Round that greater weight was given to collective interest in bilateral settlements. This occurred in the context of further legalization and the growing emphasis of the GATT/WTO as the multilateral trading system. A key document in this regard is the 1989 Improvements to the GATT Dispute Settlement Rules and Procedures. ${ }^{58}$ Considering the dispute settlement system as a

54 Ibid., at 186-187.

55 Ibid., at 159-163.

56 Ibid., at 159.

57 Ibid., at $177,185-188$.

58 Improvements to the GATT Dispute Settlement Rules and Procedures, L/6489, 12 April 1989. For more information on dispute settlement negotiations in the Uruguay Round, see J. G. Castel (1989), 'The 
'benefit of all contracting parties', 59 the membership found it necessary to harness bilateral solutions for the collective benefit. The 1989 Improvements introduced two constraints on the contractual freedom of disputants: requiring, first, MAS' conformity with the GATT and, second, their mandatory notification. ${ }^{60}$ These two innovations regulating MAS both substantively and procedurally were later incorporated in Articles 3.5 to 7 of the DSU with minor adjustments.

Hence, the evolution of the GATT's dispute settlement process goes hand in hand with a stronger regulation of bilateral settlements. Heralded as solution to the 'wrong case' problem during the Tokyo Round, it took until the Uruguay Round to effectively regulate amicable settlements through multilateral procedural and substantive safeguards in an attempt to align MAS with the interests of other stakeholders in the multilateral trading system.

\section{Defining MAS: practical and conceptual challenges}

Before proceeding to analyse how MAS are regulated in today's DSU, we must answer one question left unaddressed by the Uruguay Round: When can we speak of a MAS in the first place? While the DSU often refers to MAS, it does not define the term. So it is unclear when the regulatory obligations contained in DSU Articles 3.5-7 are triggered. One possibility to define MAS is to simply defer to WTO members: whatever agreement they formally notify as MAS pursuant to DSU Article 3.6 could be considered a MAS. ${ }^{61}$ Using notification as a benchmark for the existence of a MAS may, however, be both under-inclusive, not capturing negotiated settlements that were never notified, and over-inclusive, capturing notified agreements that actually did not provide a final 'solution' to a WTO dispute. In addition, the wording of DSU Article 3.6 stands against such an interpretation. The obligation to notify is a legal consequence arising from a MAS, but not a precondition for its existence. Hence, notification does not prove the existence of a MAS. Vice versa, non-notification of a MAS may result in a violation of DSU Article 3.6, but it does not invalidate the existence of a settlement in the first place. This is confirmed by the Appellate Body's findings in EC-Bananas III (Article 21.5-Ecuador). Instead of relying on the parties' statements in the course of notification, panels should assess the legal implication of a potential MAS

\footnotetext{
Uruguay Round and the Improvements to the GATT Dispute Settlement Rules and Procedures', International and Comparative Law Quarterly, 38(4): 834-849.

59 Improvements, supra n. 58, Article A.3.

60 Article A. 2 requires conformity of 'all solutions to matters formally raised under the GATT dispute settlement system' with GATT disciplines and further mandates that these solutions 'shall not nullify or impair benefits accruing to any contracting party under the General Agreement, nor impede the attainment of any objective of the General Agreement'. Article B.1 stipulates that MAS have to 'be notified to the Council where any contracting party may raise any point relating thereto'.

61 This approach was chosen for the WTO Analytical Index which lists only MAS notified pursuant to DSU Article 3.6, see www.wto.org/english/res_e/booksp_e/analytic_index_e/dsu_01_e.htm\#article3B5.
} 
objectively in light of the text of the agreement itself. ${ }^{62}$ Yet, what is then the benchmark used for such an objective test? Answering this question will help WTO bodies and members to better identify agreements that qualify as MAS, which give rise to the obligations in DSU Articles 3.5-7, and to solve MAS-related disputes. Aside from developing an objective definition of MAS, this section will also demonstrates the need for a two-step legal regime to streamline WTO settlement practice and explicitly regulate interim-settlements.

\subsection{Towards a definition of MAS: 'Mutually agreed ...'}

Defining MAS using an objective rather than subjective test is more challenging than it may seem at first sight given the particular design of the DSU. The most distinctive element of a MAS is its consensual nature. Disputing members negotiate and agree voluntarily on a solution to a WTO dispute. However, MAS are not the only element of amicable negotiations in the WTO dispute settlement process. In fact, the DSU's hybrid nature of negotiation and adjudication contains a number of consensual elements, leaving the disputants with considerable flexibility and control over their disputes. For instance, although WTO panels assess a challenged measure's consistency with WTO obligations, they do not, unlike judges in domestic courts, specify what a member has to do to bring a measure into compliance with WTO law. Hudec thus distinguishes between panel or Appellate Body reports as outputs of the dispute settlement process and the actual outcome of the dispute, e.g. how the respondent brings its measure into conformity. ${ }^{63}$ Due to the difference between the two, 'the outputs in WTO disputes almost always permit more than one possible compliance outcome'. ${ }^{64}$ What constitutes an acceptable compliance solution to a dispute is thus a matter of negotiation. ${ }^{65}$

The very first dispute ever brought to the WTO neatly illustrates the variety of potential consensual outcomes. It involved a complaint by Singapore over Malaysia's prohibition of imports of polyethylene and polypropylene. ${ }^{66}$ Following consultations and before the establishment of a panel, Malaysia changed its import regulation on the two substances. ${ }^{67}$ As a result, Singapore withdrew its

62 Appellate Body Report, European Communities-Regime for the Importation, Sale and Distribution of Bananas-Second Recourse to Article 21.5 of the DSU by Ecuador (EC-Bananas III (Article 21.5-Ecuador II)), WT/DS27/AB/RW2/ECU, 11 December 2008, para. 222.

63 Robert E. Hudec (1993), Enforcing International Trade Law: The Evolution of the Modern GATT Legal System, Salem, NH: Butterworth Legal Publishers, p. 276.

64 Amelia Porges, 'Settling WTO Disputes', n. 30, at 146. See also Appellate Body Report, ECBananas III (Article 21.5-Ecuador II), supra n. 62, para. 212. However, some panels or the Appellate Body may examine possible compliance paths by ways of an obiter dictum.

65 Of course, if no solution can be found, parties can resort to implementation proceedings under DSU Article 21.5 and/or arbitration under DSU Article 25.

66 Request for Consultations under Article XXIII.1 of the GATT 1994 by Singapore, Malaysia Prohibition of Imports of Polyethylene and Polypropylene, WT/DS1/1, 13 January 1995.

67 Communication from Malaysia, Malaysia-Prohibition of Imports of Polyethylene and Polypropylene, WT/DS1/3, 31 March 1995. 
complaint. In the relevant DSB meeting, 'Malaysia appreciated the cooperative spirit and understanding of Singapore's delegation in coming to an amicable solution on this matter.' 68 The withdrawal was clearly the outcome of negotiations, but a MAS was never notified pursuant to DSU Article 3.6. So the questions arises what, if anything, differentiates MAS from other consensual outcomes of a dispute, e.g. a withdrawal.

Additional consensual elements in the DSU further blur the distinction between MAS and other forms of negotiated agreements. For instance, disputing members can agree in accordance with DSU Article 21.3(b) to determine the length of the 'reasonable period of time' allowed for complying with a DSB ruling. In the dispute Mexico-Telecoms, the Panel found that certain Mexican telecommunications measures were inconsistent with the country's GATS commitments. ${ }^{69}$ Subsequently, Mexico and the US reached an Article 21.3(b) agreement. In the agreement, both countries fixed the 'reasonable period of time' at 13 months, but, in addition, set out specific compliance steps as part of a 'mutually agreed solution of the dispute'. ${ }^{70}$ Following the elapse of the 'reasonable period of time', the US expressed its satisfaction with Mexico's compliance measures. ${ }^{71}$ However, no mutually agreed solution was notified under DSU Article 3.6. So how can we identify MAS looking beyond subjective labels chosen by the notifying parties, but also without unduly conflating settlements with other consensual elements of the DSU, such as mere compliance negotiations or Article 21.3(b) agreements, which are, in principle, functionally very different from MAS?

The appropriate benchmark, against which the text of a negotiated agreement must be evaluated to objectively determine the existence of a MAS, lies in the substantive and the procedural specificities of MAS. Even in a hybrid system, amicable settlements are a procedural alternative to third-party dispute resolution. They are available throughout the stages of the DSU to pre-empt a panel report or to avoid compliance proceedings, arbitration, or retaliation. This makes MAS distinct from negotiations that take place as a result of third-party adjudication on how to bring a measure into compliance. At the same time, MAS, in principle, are substantively different from Article 21.3(b) agreements. Instead of fixing delays in compliance, MAS seek to provide a 'solution' to a dispute. Taken together, a MAS can be defined as a voluntary agreement pre-empting an adjudicatory ruling or retaliation by providing a substantive solution to a WTO dispute. In light of this

68 Minutes of the DSB Meeting on 19 July 1995, WT/DSB/M/6. 2004.

69 Panel Report, Mexico-Measures Affecting Telecommunications Services, WT/DS204/R, 1 June

70 Notification of an Agreement, Mexico-Measures Affecting Telecommunications Services, WT/ DS204/7, 2 June 2004.

71 Minutes of the DSB Meeting on 31 August 2005, held in the Centre William Rappard, WT/DSB/M/ 196. 
objective approach, at least some of the withdrawals like Malaysia-Polyethylene and Polypropylene and some Article 21.3(b) agreements like Mexico-Telecoms should also be considered as MAS. ${ }^{72}$

\subsection{The 'solution'-problem: interim $v$. final settlements}

The proposed definition, however, leads to a second problem: what is a 'solution' to a WTO dispute? Is it enough to agree on steps to resolve a dispute to have a MAS or can we only speak of a MAS once there is agreement that these compliance steps have been taken? In other words, does a MAS propose a 'solution' or does it declare a dispute resolved? The Panel and Appellate Body in EC-Bananas III (Article 21.5-Ecuador), several years prior and unrelated to the final settlement reached in 2012, struggled with this exact question. The EC had notified a 2001 agreement known as the 'Bananas Understanding' as MAS in accordance with DSU Article 3.6 as a 'solution' to its dispute with Ecuador. ${ }^{73}$ In contrast, Ecuador, in its own communication to the DSB, made clear that it did not consider the Understanding to be a MAS, stating that the agreement rather sets out implementation steps that 'can contribute to an overall, definite and universally accepted solution' once fully executed. ${ }^{74}$ The Panel took the view that an agreement had to provide 'a positive solution and effective settlement to the dispute'75 in order to qualify as MAS and that the opposing notification statements weighed against the existence of such a 'positive solution'. Although the Appellate Body disagreed with the Panel's reliance on the conflicting notifications and instead endorsed an objective approach, as outlined above, based on the agreement's text itself, it also stated that the 'mere identification of the means will not resolve the dispute'. ${ }^{76}$ The Bananas Understanding could thus only be 'a precursor to the possible conclusion of a final settlement agreement'. ${ }^{77}$ Hence, according to both the Panel and the Appellate Body, outlining negotiated implementation steps as part of an interim-settlement is not enough. To qualify as MAS, an agreement has to amount to a 'final settlement agreement'. WTO panels thus need to determine on a case-by-case basis whether it was the parties' intention, objectively manifested in the agreement they concluded, to have their dispute considered resolved for an agreement to qualify as MAS. Elements such as conditional language, expressions of expectation, or pledges of

72 Although following the distinction made under section 5.2, the Mexico-Telecom agreement may be more accurately described as interim-settlement.

73 Notification of Mutually Agreed Solution, European Communities-Regime for the Importation, Sale and Distribution of Bananas, WT/DS27/58, 2 July 2001.

74 Understanding on Bananas between Ecuador and the EC, European Communities - Regime for the Importation, Sale and Distribution of Bananas, WT/DS27/60, 9 July 2001, 1. It reads: 'it must be clear that the provisions of Article 3.6 of the DSU are not applicable in this case'.

75 Panel Report, EC-Bananas III (Article 21.5-Ecuador), supra n. 14, para. 7.107.

76 Appellate Body Report, EC-Bananas III (Article 21.5-Ecuador II)), supra n. 62, para. 219.

77 Ibid., para. 214. 
future MAS notification point to the intention to conclude an interim-settlement instead of a final settlement agreement. ${ }^{78}$

The distinction between final settlements qualifying as MAS and interimsettlements stands in contrast to WTO practice as WTO members have notified both types of agreements as MAS under Article 3.6. In Japan-Sound Recordings, the parties declared a solution only after an amendment was made to the Japanese copyright law. ${ }^{79}$ In contrast, a MAS between Argentina and the US over the former's patent law was already notified before and subject to subsequent domestic implementation. ${ }^{80}$ The Panel and the Appellate Body, however, are correct in making a distinction between interim-settlements proposing to solve a dispute and final settlements declaring a dispute resolved. An agreement in which both parties assert their understanding that a dispute is resolved should have a different legal effect and follow-up mechanism than a document which merely sets out compliance steps requiring further implementation. Unfortunately, the DSU, as it stands today, only addresses the former (through MAS) but not the latter.

It is this gap in the DSU that WTO members are reacting to by their emerging practice of concluding MoUs and sui generis settlements. ${ }^{81}$ Before committing to a final settlement through MAS, these agreements allow members to work towards the solution of a dispute. In principle, these interim-settlements are thus meant to bridge a legal gap and to complement rather than to substitute MAS. This is evidenced by the fact that MoUs and sui generis settlements always foresee future MAS notification as final settlement. What makes their relationship problematic in practice, however, is that past MoUs or sui generis agreements have not always been followed by a final settlement and subsequent Article 3.6 MAS notification. ${ }^{82}$

78 See also ibid., paras. 217-220. To clarify, also MAS understood as final settlements may require future implementation action, e.g. by complying with an agreed yearly reduction of tariffs. This alone does not make it an interim-settlement. What counts is whether the parties' intention, objectively manifested in the agreement, suggests a final settlement agreement (MAS) or merely the roadmap towards such an agreement (interim-settlement).

79 Notification of a Mutually Agreed Solution, Japan-Measures concerning Sound Recordings, WT/ DS42/4, 17 November 1997.

80 Notification of Mutually Agreed Solution According to the Conditions Set Forth in the Agreement, Argentina-Patent Protection for Pharmaceuticals and Test Data Protection for Agricultural Chemicals, WT/DS171/3, and Argentina - Certain Measures on the Protection of Patents and Test Data, WT/DS196/ 4, 20 June 2002.

81 Another reason why members conclude MoUs may be the inherent informality associated with these instruments. In the context of general international law, Aust submits that states conclude MoU as mere 'diplomatic assurances' which, unlike international treaties, do not create legally binding rights and obligations. See Anthony Aust (2007), Modern Treaty Law and Practice, 2nd edn. Cambridge University Press. In the WTO context, this argument has less weight, as MAS are not per se legally enforceable (see section 6). The only major substantive difference between MoUs and MAS is the former's explicit interimsettlement nature.

82 One instance in which a MoU was followed by a MAS is the case Joint Communication from China and the United States, China - Value-Added Tax on Integrated Circuits, WT/DS309/7, 16 July 2004 and Notification of Mutually Agreed Solution, WT/DS309/8, 6 October 2005. 
Hence, disputes risk remaining formally 'pending' indefinitely, while it is unknown to all but the parties involved whether the agreed compliance steps have actually been taken. As a result, due to a lack of formality and follow-up this new practice currently seems to be undermining rather than complementing the role of MAS in the WTO.

\subsection{Conclusion: the need for a two-step settlement procedure}

Grounded in both the wording of the DSU and Appellate Body jurisprudence, it has been shown that the existence of a MAS needs to be determined objectively as a voluntary agreement pre-empting an adjudicatory ruling or retaliation by providing a final solution to a WTO dispute. To arrive at such a final settlement, WTO members increasingly conclude informal interim-settlements not addressed by the DSU. Negotiators should close this gap in the DSU by introducing and regulating the separate category of interim-settlements explicitly. Amicable settlements of WTO disputes could thus be streamlined as a two-step procedure as was de facto done in the recent EC-Bananas settlement. First, in 2009 the 'Geneva Agreement on Bananas' was concluded as an interim-settlement, ${ }^{83}$ then, in 2012, upon scrutiny by the WTO membership as well as the interested public, ratification and domestic implementation, a MAS was notified as final settlement. ${ }^{84}$ Unfortunately, the degree of transparency and follow-up achieved by the high-profile nature of the Bananas dispute is absent in less well-publicized cases. Hence, for all disputes to benefit from an equally streamlined two-step procedure, the DSU has to be amended. First, interim-settlements should be governed by the same notification and commentating procedure as MAS in Article 3.6. In addition, they should be subject to continuous progress reporting in order to facilitate their implementation. Second, once an interim-settlement is implemented, the parties are required to notify the final settlement as MAS (see section 7 for drafting suggestion). Such a two-step procedure fully accommodates the competing bilateral and multilateral interests in settlements: it allows the disputing parties to work towards a final settlement in a structured and transparent manner, alleviates power asymmetries by placing interim-settlement negotiations into the 'shadow of the law', and, finally, safeguards collective interests by bringing otherwise informal negotiations into the official DSU process where it can be subject to full scrutiny.

\section{The procedural and substantive law of MAS in DSU Articles 3.5-7}

Having identified the agreements that are considered as MAS and that trigger the obligations of Articles 3.5-7, we can finally turn to how the DSU balances the

83 Communication from Brazil, Colombia, Costa Rica, Ecuador, European Union, Guatemala, Honduras, Mexico, Nicaragua, Panama, Peru, and the Bolivarian Republic of Venezuela, Geneva Agreement on Bananas, WT/L/784, 15 December 2009.

84 Notification of Mutually Agreed Solution, EC-Bananas, supra n. 2. 
competing bilateral and multilateral interests involved in settlements. This section sheds light on the mechanisms and the success of this balancing framework which facilitates, constrains, and regulates amicable settlements in the multilateral trading system.

\subsection{The procedural law of MAS}

\section{Disputants I: legal effects of MAS}

When opting for a settlement instead of adjudication, disputants have an interest in enforcing the terms of a MAS and to prevent the other party from reneging on its MAS commitments. Yet, MAS display important differences compared to the status and effect of the alternative DSU remedy of adjudication, which need to be borne in mind. Unchallenged panel reports and Appellate Body findings arguably have the status of a res judicata. ${ }^{85} \mathrm{~A}$ member may hence not raise a claim relating to the same matter, parties, and cause of action twice. In other words, adjudication conclusively determines the (il)legality of an allegedly WTO inconsistent measure. The impact of a MAS on a dispute is less clear as the DSU is silent on the legal effect of MAS and the possibility of their enforcement. ${ }^{86}$ Can a member hence challenge a measure after having settled a dispute over that same measure in a MAS? Guidance can be found in case law. The Panel in India-Autos was faced with that question. India argued that a MAS concluded with the EC over the prior dispute IndiaQuantitative Restrictions ${ }^{87}$ precluded the EC from bringing a new challenge. Remarking that the DSU is silent on the impact of MAS on subsequent proceedings, ${ }^{88}$ the Panel faced a dilemma between preserving members' right to a panel and giving effect to a MAS as 'clearly to be preferred' DSU remedy. ${ }^{89}$ The Panel solved the problem by noting that this question has to be answered on a case-by-case basis and that, in the present dispute, the terms of the earlier MAS did not cover the specific issues raised in the newer dispute. ${ }^{90}$ Finally, the Panel stressed that this

85 Mitsuo Matsushita, Thomas J. Schoenbaum, and Petros Mavroidis (2006), The World Trade Organization: Law, Practice and Policy, New York: Oxford University Press, pp. 84-85. The Panel in India-Autos dealt with the question of a possible application of the principle in WTO law. While it found that its conditions had not been met in the specific case, the Panel was sympathetic to the possible existence of a res judicata effect in WTO law. However, it refrained from explicitly deciding this systemic issue. See Panel Report, India-Measures Affecting the Automotive Sector (India-Autos), WT/DS146/R, WT/DS175/ R, 21 December 2001, paras. 7.54-7.103.

86 Alvarez-Jiménez, 'Mutually Agreed Solutions', supra n. 4, at 348.

87 Notification of Mutually Agreed Solution, India-Quantitative Restrictions, supra n. 24.

88 Panel Report, India-Autos, supra n. 85, para. 7.113.

89 Ibid., para. 7.115: 'Without clear guidance in the DSU, this question raises an important systemic issue. On the one hand, the Panel recognizes that the right for any WTO Member to bring a dispute to the DSB is one of the fundamental tenets of the DSU, and that it could not be lightly assumed in what particular circumstances the drafters of the DSU might have intended such right to be foregone. On the other hand, it may also be the case that it could not be lightly assumed that those drafters intended mutually agreed solutions, expressly promoted by the DSU, to have no meaningful legal effect in subsequent proceedings.'

90 Ibid., paras. 7.115-7.132. 
finding is without prejudice to the general legal question 'whether a notified mutually agreed solution can ever operate as a bar to a panel's express mandate from the DSB'. 91

A similar strategy was adopted by the later Panel EC-Bananas III (Article 21.5 - Ecuador), already discussed above, which had to decide whether a MAS, the Bananas Understanding, concluded during the implementation stage, could preclude a claimant from requesting compliance proceedings under DSU Article 21.5. While the Panel indicated that it would follow the India-Autos approach of a casespecific analysis, ${ }^{92}$ it stated in a more general way that 'the Bananas Understanding can legally bar Ecuador from bringing this compliance challenge only if that Understanding constitutes a positive solution and effective settlement to the dispute in question'. 93 The Panel went on to apply this 'positive and effective solution' test to the Bananas Understanding. It addressed the substantive obligations underlying a MAS and concluded that the 'complainant must have the possibility of having recourse to WTO dispute settlement in order to review the conformity with the covered agreements of a measure purportedly taken by the respondent to implement a step set out in an alleged mutually agreed solution or other legally binding agreement'. ${ }^{94}$ On appeal, the Appellate Body overturned the Panel's reasoning and stressed the flexibility and contractual freedom of the parties. Whether a MAS constitutes a 'positive and effective solution' to a dispute has no bearing on whether or not a complainant has access to 21.5 proceedings. The question is rather whether the terms of a MAS indicate 'the agreement between the parties of a relinquishment of the right to have recourse to Article 21.5 ${ }^{95}$ The Appellate Body thus refrained from attributing to MAS the effect of precluding further proceedings per se and, instead, stressed the contractual freedom of the disputants in a MAS. In consequence, the legal effect of a MAS has to be assessed on a case-by-case basis in light of the actual terms of the agreement.

\section{Disputants II: enforcement}

Another important difference in settlements compared to WTO adjudication relates to the enforcement of MAS. A panel or Appellate Body decision, once adopted by the DSB, entails a commitment on the part of the respondent state to bring a measure, found to be inconsistent with the WTO agreements, into conformity. Once such a decision is rendered, the DSU provides for a detailed followup mechanism. A complainant unsatisfied with the respondent's compliance can request the establishment of a DSU Article 21.5 compliance panel. If the respondent

91 Ibid., para. 7.134.

92 Panel Report, EC-Bananas III (Article 21.5-Ecuador), supra n. 14, para. 7.59.

93 Ibid., para. 7.75.

94 Ibid., para. 7.91.

95 Appellate Body Report, EC-Bananas III (Article 21.5-Ecuador II), supra 62, para. 212. 
fails to comply, the complainant can request retaliation rights pursuant to DSU Article 22.

No such follow-up mechanism exists with respect to MAS. According to the conventional view, parties cannot, in principle, enforce the provisions of a settlement through WTO panels. DSU Article 1.1 makes clear that the jurisdiction of panels is limited to the WTO covered agreements and MAS are not part thereof. ${ }^{96}$

In an article published in 2011 in this journal, Alvarez-Jiménez presents an alternative view. Reacting to the 2006 Softwood Lumber settlement of several WTO disputes between Canada and the United States which provided for a selfstanding commercial arbitration mechanism to solve MAS-related disputes, Alvarez-Jiménez argues that WTO panels should and can assume jurisdiction over MAS-related controversies. He demonstrates in a detailed legal analysis that the jurisdiction of panels over MAS can be grounded in DSU Article 3.3 read together with Article 3.7, since a MAS creates rights and obligations accruing indirectly out of the DSU - a WTO agreement. ${ }^{97} \mathrm{He}$ also shows that MAS are applicable law under the DSU and explores various procedural implications of having MAS litigated at the WTO. ${ }^{98}$

There are, however, a number of legal and judicial policy considerations that militate against his argument. First, it is doubtful whether a panel or the Appellate Body would follow Alvarez-Jiménez's reading of the DSU, since Article 3.3 merely provides contextual language, whereas DSU Article 1.1, in which the word 'indirectly' is absent, sets out the jurisdictional scope of the WTO dispute settlement. Second, the Appellate Body as outlined above has so far stressed the contractual freedom of the parties to a MAS and declined to attribute any automatic legal effects to these agreements. Already today, WTO members can provide for an independent enforcement mechanism in their MAS, if they wish to do so. As Shoyer suggests, WTO members can even foresee WTO-based arbitration pursuant to DSU Article 25 in their MAS, which would then be subject to the DSU's follow-up mechanism in Articles 21 and 22. ${ }^{99}$ Opting for an automatic enforcement of MAS would be a reversal of the existing approach in case law and would frustrate the intention of those parties to a MAS that purposefully refrained from including any enforcement mechanism in their agreement under the legal expectation that their contractual choices would be observed. Third, Alvarez-Jiménez points to the Softwood Lumber Agreement (SLA), as one of the examples when WTO members

96 Burnier da Silveira et al., 'Die Bedeutung der konsensualen Elemente', supra n. 17, at 49.

97 Alvarez-Jiménez, 'Mutually Agreed Solutions', supra n. 4, at 353-357.

98 Ibid., at 360-362. Also other authors have suggested that MAS could be applicable law before a WTO Panel, see Laurent Bartel (2001), 'Applicable Law in WTO Dispute Settlement Proceedings', Journal of World Trade, 35(4): 499-519.

99 Andrew W. Shoyer (1998), 'The First Three Years of WTO Dispute Settlement: Observations and Suggestions', Journal of International Economic Law, 1(2): 277-302, at 289. 
made use of their contractual flexibility to set-up an independent enforcement mechanism, to demonstrate the need for an automatic WTO-based MAS enforcement. In fact, the SLA points to the opposite conclusion. The SLA did not only solve a number of WTO disputes but settled 20 national, NAFTA, and WTO litigations. In such a multi-level and multi-jurisdictional context, a 'customized interstate arbitration vehicle' is in a much better position than a WTO panel to manage issuespecific, cross-jurisdictional disputes and to bring some order into the spaghetti bowl' of overlapping trade agreements. Forth, the rise of interim-settlements and decline of MAS shifts disputes over implementation to MoUs and sui generis settlements. As interim-settlements, these agreements would not benefit from the automatic enforceability of MAS. Integrating these agreements in a structured and transparent two-step settlement procedure as proposed above would also help address disputes over their implementation. Finally, MAS enforceability is currently one of the controversial issues discussed in the on-going DSU reform debate (see section 7). So even if there were a genuine need for automatic enforcement, the Appellate Body would be wise to leave such a controversial topic to the WTO membership rather than to pre-empt the outcome of negotiations.

\section{Collective stakeholders I: notification as procedural safeguard}

The notification requirement of MAS in DSU Article $3.6^{100}$ serves to harmonize instant dispute resolution with collective stakes. As discussed above, confidentiality and privacy are needed to facilitate MAS, but they come at the expense of procedural transparency. The DSU resolves this dilemma by recognizing and maintaining procedural confidentiality during negotiations but introducing ex ante and ex post transparency through notification. Ex ante, WTO consultation requests are notified and hence made known to other members and the interested public pursuant to DSU Article 4.4. In addition, DSU Article 4.11 allows WTO members with a 'substantial trade interest' to join the consultation. ${ }^{101}$ Busch and Reinhardt, however, find that the inclusion of third parties in the consultation phase significantly decreases the odds of a settlement. ${ }^{102}$ If a MAS is reached, it must be notified ex post to the DSB and other relevant WTO bodies 'where any member may raise any point relating thereto' as stipulated in DSU Article 3.6. Hence, as Baroncini puts it:

the diplomatic nature of the conclusion of a WTO dispute by no means entails that the amicable settlement may be considered as a private business between the

100 DSU Article 3.6: 'Mutually agreed solutions to matters formally raised under the consultation and dispute settlement provisions of the covered agreements shall be notified to the DSB and the relevant Councils and Committees, where any Member may raise any point relating thereto.'

101 To demonstrate a 'substantial trade interests', it is generally enough to claim 'systemic interests' in the dispute. The defendant may object the inclusion, in which case the third party may issue its own consultation request. See Busch and Reinhardt, 'Bargaining in the Shadow of the Law', supra n. 32, 76.

102 Ibid. 
parties involved in the controversy but, on the contrary, is seen - in the same way as it happens for third party binding decisions - as an act of general interest with reference to which the WTO system guarantees a right of immediate knowledge and comment. ${ }^{103}$

The DSU is silent, however, on how exactly MAS' ex post notification in DSU Article 3.6 is to be done. Particularly, it is unclear who has to notify, how detailed notification has to be, and when it has to be made. In practice, this ambiguity has created considerable problems. Although conflicting notification such as in the above mentioned case of the Bananas Understanding are rare and the majority of MAS are notified by both parties, ${ }^{104}$ the Bananas dispute demonstrates that DSU Article 3.6 would benefit from further clarification as to whether both parties are under an obligation to notify. Similarly, the notification practice is highly divergent when it comes to detail and timing. The arguably most extreme case involves a dispute between Hungary and Croatia over the latter's SPS import measure allegedly adopted to prevent the spread of BSE. Hungary filed a consultation request in July 2003. Almost six years later, in February 2009, both countries notified the DSB that a MAS had already been reached in 2003. The communication's part relevant to the MAS is limited to the sentence: 'On behalf of our authorities we would like to inform you that Hungary and Croatia did find a mutually satisfactory solution to this case in 2003.' ${ }^{105}$ No further detail was provided. Baroncini concluded in her 1998 research on MAS that a notification that lacks detail and is not promptly made fails to function as means to safeguard third parties' stakes. ${ }^{106}$ This can only be reiterated in light of such more recent practice.

Notification, if properly done, can be a procedural safeguard for the collective interests involved in MAS. First, domestic stakeholders learn about the terms of the settlement and can scrutinize their government's decision based on this information. Second, DSU Article 3.6 'ensure[s] that all WTO Members may review mutually agreed solutions for consistency with WTO obligations' ${ }^{107}$ In other words, notification allows third WTO members to monitor whether a settlement was made at their expense and potentially claim MFN benefits arising out of the settlement. In contrast to direct participation of third countries in consultations, such ex post notification of MAS does not diminish the likelihood of a MAS being reached. ${ }^{108}$ Third, notification is also crucial for the WTO system at large as a

103 Baroncini, 'The WTO Dispute Settlement Understanding', supra n. 4, 243.

104 Panel Report, EC-Bananas III (Article 21.5 - Ecuador), supra n. 14, para. 7.105.

105 Request for Consultations by Hungary-Addendum, Croatia-Measure Affecting Imports of Live Animals and Meat Products (WT/DS297/2), 2 February 2009.

106 Baroncini (1999), The WTO Dispute Settlement Understanding', supra n. 4, at 259. In particular, this precludes third members from monitoring the consistency of settlements.

107 Background Note by the Secretariat, Notification of Mutually Agreed Solutions under Article 3.6 of the Dispute Settlement Understanding, WT/DSB/W/35, 7 August 1996.

108 Busch and Reinhardt, 'Bargaining in the Shadow of the Law', supra 32. 
properly notified MAS could produce valuable guidance on ways in which contentious and long-standing WTO disputes can be solved amicably. ${ }^{109}$

\section{Collective Stakeholders II: challenging a MAS}

DSU Article 3.6 provides a second control mechanism according to which 'any member may raise any point relating' to MAS in the relevant WTO bodies. The term 'any point' may refer to further clarification requests, but also to objections against elements in a MAS that undermine third party rights. ${ }^{110}$ While Article 3.6 provides for a purely diplomatic mechanism to check and potentially challenge the WTO consistency of MAS, a WTO member also has the possibility to lodge a formal request for consultation against one of the parties to a settlement on the grounds that a measure enacted pursuant to a MAS nullifies or impairs benefits accruing to it under the WTO agreements. ${ }^{111}$ However, a more direct surveillance mechanism to systematically verify the consistency of MAS with WTO law is missing in the DSU.

\subsection{The substantive law of MAS}

While, in principle, MAS offer greater flexibility to disputants than panel adjudication, the DSU also places limits on the contractual freedom of the disputants and includes substantive requirements to harmonize a MAS with the interests of other stakeholders.

DSU Article 3.6 confines MAS to 'matters formally raised under the consultation and dispute settlement provisions of the covered agreements'. Hence, only disputes subject to a request for consultation pursuant to DSU Article 4.4 can be settled in a MAS. ${ }^{112}$ Furthermore, Shanker interprets this provision to limit the content of a MAS to the precise issues raised in the consultation request. ${ }^{113}$ This would limit the ability of WTO members to conclude 'WTO+' MAS encompassing additional issues and side-payments. However, the object and purpose of DSU Article 3.6 is to set out the notification requirement of settlements to WTO disputes and not to limit the substantive contents of these settlements. ${ }^{114}$ Therefore, disputants can include issues in their MAS that were not specified in the request for consultation as long as

109 In that vein, Baroncini argues that MAS deserve as much attention as panel or Appellate Body reports. See Baroncini, 'The WTO Dispute Settlement Understanding', supra n. 4, at 244.

110 For greater details and examples, see ibid., at 261-263.

111 It must be stressed that the success of such a request may nevertheless be closely linked to the notification of a MAS. Under the DSU, the burden of proof is on the complainant to show a breach of the covered agreements, which is then presumed to constitute a prima facie case of nullification or impairment pursuant to DSU Article 3.8. Hence, the complaining member has to gather enough evidence to mount such a prima facie case, which may be more difficult if the notification is incomplete or not detailed enough.

112 Alvarez-Jiménez, 'Mutually Agreed Solutions', supra n. 4, at 347-348.

113 Shanker, 'Argentina-US Mutually Agreed Solution', supra n. 33, at 568.

114 Background Note by the Secretariat, supra n. 107. 
they form part of a 'package deal' that provides a final settlement to the 'matters formally raised' by the complainant.

Other parts of the DSU, however, do regulate the content of MAS. DSU Article $3.5^{115}$ is an umbrella provision that deals with 'all solutions to matters formally raised' before the WTO. This includes arbitration awards as specifically mentioned, but also MAS as well as outcomes reached following panel or Appellate Body reports. In order to be a valid 'solution', MAS have to meet three criteria: they have to '[1] be consistent with those agreements and [2] shall not nullify or impair benefits accruing to any Member under those agreements, [3] nor impede the attainment of any objective of those agreements'. Together with Article 3.7 that reiterates the requirement of consistency for MAS, these three criteria embody the substantive balancing considerations in the DSU limiting the contractual freedom of the disputants with respect to settlements and safeguarding the interests of other stakeholders. An agreement that fails to meet these criteria cannot amount to a 'solution' within the meaning of these provisions. So even though a settlement may provide a 'final solution' for the disputing parties, as objectively determined on the basis of the text of the agreement, and thus qualify as MAS (see section 5), noncompliance with DSU Article 3.5 and 3.7 will render such a MAS null and void in its entirety for the sake of protecting collective interests. ${ }^{116}$ Let us now discuss these requirements from the different balancing angles beginning with the contractual freedom of disputants.

\section{Disputants: contractual freedom to conclude 'WTO-'/'WTO +' settlements?}

The DSU categorically mandates MAS to be 'consistent with' the covered agreements. The Appellate Body clarified a similarly worded term in Article 5.1 of China's Accession Protocol '[w]ithout prejudice to China's right to regulate trade in a manner consistent with the WTO Agreement' in the case China-Audiovisuals. ${ }^{117}$

115 DSU Article 3.5: 'All solutions to matters formally raised under the consultation and dispute settlement provisions of the covered agreements, including arbitration awards, shall be consistent with those agreements and shall not nullify or impair benefits accruing to any Member under those agreements, nor impede the attainment of any objective of those agreements.' The same requirement of consistency is repeated in DSU Article 3.7.

116 Alvarez-Jiménez, 'Mutually Agreed Solutions', supra n. 4, at 352 suggests that a partial inconsistency of a MAS may not led to its invalidity. However, the text of DSU Article 3.5 makes clear that only WTO compliant outcomes can constitute a 'solution'. Allowing partially inconsistent MAS because they may contain 'other clauses ... effective to resolve the dispute' would disregard the effet utile of the provision that aims to protect collective interests in settlements by expressly limiting the contractual freedom of the disputants. This reading also finds support in the general WTO practice of leaving it to members, and not to panels or the Appellate Body, to decide on how to bring a WTO-inconsistent legal instrument back into WTO conformity. MAS contracting parties are perfectly free to adjust the terms of their agreement to benefit from DSU Articles 3.5 and 3.7.

117 Appellate Body Report, China-Measures Affecting Trading Rights and Distribution Services for Certain Publications and Audiovisual Entertainment Products, WT/DS363/AB/R, 21 December 2009 (emphasis added). 
The Appellate Body stated that 'WTO Members' regulatory requirements may be WTO consistent in one of two ways. First, they may simply not contravene any WTO obligation. Second, even if they contravene a WTO obligation, they may be justified under an applicable exception'. ${ }^{118}$ Applied to the MAS context, this means that to be WTO-consistent settlements must conform with all WTO obligations, but can also benefit from the flexibilities granted by the covered agreements, e.g. their exceptions. Conversely, it can also be inferred from the passage that MAS that are acting against a WTO obligation and do not benefit from an exception are 'inconsistent with' the covered agreements. Therefore, a MAS that contracts out of a WTO obligation without being justified by the covered agreements themselves would be inconsistent with DSU Articles 3.5 and 3.7.

MAS can thus not diminish WTO obligations. But can they diminish rights granted by the WTO agreements and still be consistent with the covered agreements? For instance, is the already mentioned MAS practice of waiving a right to further DSU recourse inconsistent with Article 3.5? Diminishing rights could conflict with the second requirement of DSU Article 3.5 mandating that MAS 'shall not nullify or impair benefits accruing to any Member under those agreements'. The term 'any member' includes the disputants. As the Panel in ECBananas III (Article 21.5-Ecuador) pointed out: 'it is first and foremost the benefits accruing to the complainant in the dispute that might be affected [by a MAS]'.119

The non-exercise or waiving of rights does not conflict with DSU Article 3.5 for a number of reasons. In public international law, it is generally accepted that states can waive rights and claims as long as the exercise of their international obligations remains unaffected. ${ }^{120}$ WTO law mirrors general international law in this respect. The Appellate Body stated in EC-Poultry with respect to the ordinary meaning of the word 'concession' that 'a Member may yield or waive some of its own rights and grant benefits to other Members, but that it cannot unilaterally diminish its own obligations'. ${ }^{121}$ Hence, members cannot diminish their own obligations, but they can waive or choose not to exercise their own rights.

A specific outgrowth of the general principle of waiving rights is found in the ILC Articles on State Responsibility Article 45, which states that an injured state may not invoke the responsibility of another state if, previously, it has validly waived its right of standing. The freedom of states to waive a right of standing is also recognized in WTO law. This links back to the discussion in the previous section on

118 Ibid., para. 223.

119 Panel Report, EC-Bananas III (Article 21.5-Ecuador), supra n. 14, para. 7.106.

120 Waivers are recognized as unilateral acts that can bind states internationally, see Krzysztof Skubiszewski (1991), 'Unilateral Acts of State', in Mohammed Bedjaoui (ed.), International Law Achievements and Prospects, Paris: UNESCO, pp. 221-240.

121 Appellate Body Report, European Communities - Measures Affecting the Importation of Certain Poultry Products, WT/DS69/AB/R, 13 July 1998, para. 98. 
the EC-Bananas III (Article 21.5-Ecuador) case and the emphasis placed by the Appellate Body on the terms of a MAS when evaluating their effects. While rejecting that a MAS per se 'necessarily implies that parties waive their rights to have recourse to the dispute settlement system',122 the Appellate Body acknowledged the contractual freedom of the disputants by stating that 'a mutually agreed solution pursuant to Article 3.7 may encompass an agreement to forego the right to initiate compliance proceedings'. ${ }^{123}$ Such agreement, however, must be clearly indicated. ${ }^{124}$ If this is the case, the waiver of standing in a MAS could constitute a 'legal impediment to the exercise of a panel's jurisdiction'. ${ }^{125}$ Such a legal impediment is different from a legal effect equivalent to res judicata rejected above and relates instead to the individual member's right of standing that is waived. The respondent can thus use a MAS as a defence before a WTO panel to prevent the claimant from exercising a right that has explicitly been waived in a MAS.

Waiving of a procedural right of standing can also have a comparable effect to an explicit contracting-out of obligations. If two members agree not to challenge a measure in violation of a WTO obligation, they tacitly accept that violation. Such arrangements may be particularly likely in disputes involving de facto counter claims. ${ }^{126}$ For instance, in a dispute over Brazil's patent law and its compulsory licensing system on antiviral drugs, ${ }^{127}$ the US accepted a settlement establishing a bilateral dialog and leaving the challenged measure intact, once Brazil came forth with its own claim ${ }^{128}$ against provisions of the US Patent Code. ${ }^{129}$ In the letter exchange notified as a MAS, the US Trade Representative wrote: 'In addition, we would expect Brazil not to proceed with further dispute settlement action regarding sections 204 and 209 of the U.S. patent law.' ${ }^{130}$ While this understanding may not amount to a binding or formal waiver, it demonstrates how a MAS can be used to tacitly agree on a non-exercise of rights amounting de facto to the acceptance of a violation. $^{131}$

122 Appellate Body Report, EC-Bananas III (Article 21.5 - Ecuador II), supra n. 62, para. 212.

123 Ibid.

124 Ibid.

125 Appellate Body Report, Mexico - Tax Measures on Soft Drinks and Other Beverages, WT/DS308/ $\mathrm{AB} / \mathrm{R}, 6$ March 2006.

126 DSU Article 3.10 limits the use of counter claims. The term is used here to describe parallel proceedings in which two WTO members challenge each other on similar grounds.

127 Brazil-Measures Affecting Patent Protection, WT/DS199.

128 United States - Patent Code, WT/DS244.

129 Viviana Muños Tellez (2010), 'Dispute Settlement under the TRIPS Agreement: The United StatesBrazil (2000) and United States-Argentina (2002) Patent Disputes', in Carlos M. Correa (ed.), Research Handbook on the Interpretation and Enforcement of Intellectual Property under WTO Rules, Cheltenham: Edward Elgar Publishing, pp. 215-236, at 223.

130 Notification of Mutually Agreed Solution, Brazil-Measures Affecting Patent Protection, WT/ DS199/4, 19 July 2001.

131 Other WTO members outside the MAS remain of course free to bring a claim. 
Beyond the waiving of standing, the WTO also more generally recognizes the possibility of waiving procedural rights. In Canada-Continued Suspension, for example the parties 'waived their right to confidentiality and requested open hearings'.132 Furthermore, members are also free to take on new trade-related obligations that limit rights and flexibilities granted under the WTO covered agreements, such as 'TRIPS +', 'TRIMS +' or generally 'WTO +' commitments, in a MAS. ${ }^{133}$ This may amount to a de facto waiver of substantive rights. In conclusion, members may voluntarily waive rights or forego benefits accruing to them under the covered agreements in a MAS without violating DSU Article 3.5. It also follows that a member can use a MAS as defence before a WTO panel to prevent the exercise by another member of rights that have been validly waived in a MAS.

\section{Collective stakeholders: substantive safeguards}

DSU Article 3.5, especially in its second and third requirement, is also directed towards safeguarding the interests of other stakeholders. The second requirement stipulates that MAS may not nullify or impair benefits accruing to third WTO members. Not only does this provision make clear that MAS cannot be achieved at the expense of other states, but also that MAS cannot be used to prevent members from enjoying the benefits accruing to them under the covered agreements. Bilateral concessions granted in MAS, therefore, have to be multilateralized by virtue of the MFN obligation. Furthermore, the third requirement in DSU Article 3.5 states that MAS shall not 'impede the attainment of any objective of those agreements'. This refers to the collective interests of the WTO membership at large in preventing MAS that go against the spirit of the WTO agreements.

Guidance on the interpretation of these two requirements may be found in general international law. Taken together, the second and third requirements in DSU Article 3.5 mirror the conditions attached to inter se modifications of multilateral treaties under the Vienna Convention on the Law of Treaties (VCLT) Article 41.134 Underlying the conditions in the VCLT is a distinction between two kinds of multilateral treaties: those containing obligations that can be reduced to a bundle of bilateral relationships and those that are collective in nature and are owed to the treaty membership as a whole. ${ }^{135}$ Bilateral obligations in multilateral treaties may be modified inter se without contravening the rights of other members

132 Panel Report, Canada - Continued Suspension of Obligations in the EC-Hormones Dispute, WT/ DS321, 31 March 2008, para 7.49.

133 See also Alvarez-Jiménez, 'Mutually Agreed Solutions', supra n. 4, at 349-350.

134 The VCLT permits such modification provided that the multilateral treaty allows it or, alternatively, that it does not explicitly prohibit it and that two supplementary conditions are met: the modification '(i) does not affect the enjoyment by the other parties of their rights under the treaty or the performance of their obligations and (ii) does not relate to a provision, derogation from which is incompatible with the effective execution of the object and purpose of the treaty as a whole.'

135 Joost Pauwelyn (2003), 'A Typology of Multilateral Treaty Obligations: Are WTO Obligations Bilateral or Collective in Nature?', European Journal of International Law, 14(5): 907-951, at 908. 
or a treaties' objective. Collective obligations, in contrast, relate to third party rights and common values transcending individual parties' interest. They can therefore not be modified inter se without affecting the enjoyment of other members' rights and frustrating an agreement's purpose. ${ }^{136}$

Applying the distinction to the WTO, Pauwelyn concludes that WTO obligations are essentially bilateral in nature. The object of WTO disciplines is the regulation of trade, which is an inherently bilateral activity. Since WTO obligations can be individualized, they are bilateral in nature and inter se modifications are possible. ${ }^{137}$ Carmody, on the other hand, argues that these obligations are in fact better understood as collective. He contends that the WTO does not regulate trade, but 'expectations concerning trade-related behavior of governments' ${ }^{138}$ In that case, inter se modification would be impossible as this would violate the rights of third parties and frustrate the objectives of the WTO agreements.

The divergent views expressed in that debate highlight how difficult it is to identify the 'objective' of an agreement. While it may be relatively easy to determine whether an inter se modification or a settlement infringes on third party rights, it is far less clear when a MAS impedes the attainment of a WTO objective. Pauwelyn argues that the two elements in VCLT Article 41 - the protection of third party rights and the impediment of an agreement's objective - are deeply intertwined. ${ }^{139}$ Indeed, also for MAS, it is difficult to imagine a settlement that would be consistent with WTO agreements and respect third party rights, meeting the first two criteria of DSU Article 3.5, but that still impedes an objective of the covered agreements. Consequently, the third requirement of DSU Article 3.5 may only prove decisive in rare circumstances in which it can function as a safety net that prevents MAS that exceed the degree of flexibility given to the disputants and risk unduly fragmenting the multilateral trading system. Table 2 summarizes the findings of this section.

\section{Amicable settlements and the DSU reform}

Introduced during the Tokyo Round, MAS have fulfilled their primary purpose of adding stability to the multilateral trading system by providing negotiated solutions to hard or 'wrong cases'. The challenge remains, however, to find a suitable middle ground between preserving the contractual freedom of disputants while safeguarding third party and collective interests. Although, as this article has shown, the DSU is relatively successful in balancing the different stakes and stakeholders in MAS, there is certainly room for improvement. Particularly the issues of notification and enforcement of MAS have featured prominently in recent efforts

136 Ibid., at 914.

137 Ibid., at $928-936$.

138 Chios Carmody (2006), 'WTO Obligations as Collective', European Journal of International Law, 17(2): 419-443, at 421.

139 Pauwelyn, ‘A Typology of Multilateral Treaty Obligations', supra n. 135, at 915. 
Table 2. Summary table - stakes, stakeholders and the law of MAS

\begin{tabular}{|c|c|c|c|}
\hline \multirow[b]{2}{*}{ Stake-holders } & \multirow[b]{2}{*}{ Stakes } & \multicolumn{2}{|c|}{ DSU } \\
\hline & & Procedure & Substantive outcome \\
\hline Disputants & Flexibility & $\begin{array}{l}\text { MAS are possible throughout the stages of the DSU in } \\
\text { accordance with DSU Articles } 3.7,4.3,11,12.7,15 \text {, } \\
22.2 \text {, and } 22.8 \text {. }\end{array}$ & $\begin{array}{l}\text { DSU Articles } 3.5 \text { and } 3.7 \text { prohibit MAS that diminish } \\
\text { WTO obligations; however, disputants can waive } \\
\text { rights such as standing (WTO-) and add to rights and }\end{array}$ \\
\hline
\end{tabular}

Power asymmetry In the DSU's hybrid system of negotiation and

obligations in their settlements (WTO+).

Confidentiality and adjudication, the right to a panel casts a 'shadow of the law' over negotiations between the parties that alleviates power asymmetries.

privacy in settlement

DSU Article 4.6 mandates consultations to be confidential.

DSU Article 4.11 provides that the respondent can object to the inclusion of third parties in the consultations if their claim of substantial interest in the dispute is not well-founded.

Compliance/

Mandatory notification increases the reputation costs enforcement

of reneging on a MAS commitment improving compliance.

Disputants can include a separate enforcement mechanism in their MAS, e.g. arbitration (see SLA) including under DSU Article 25.

Disputants can challenge the original measure again unless they have waived their right to bring such a proceeding in their MAS. 
Domestic stakeholders, Transparency of MAS third WTO members,

WTO system

\section{Third WTO}

members

WTO system
Participation in

consultation

Challenging a

settlement

Violation of third party

rights in settlements

Fragmentation or

circumvention of

WTO law ex ante: Requests for consultations have to be notified

in detail pursuant to DSU Article 4.4.

ex post: A MAS has to be notified to all relevant

Councils and Committees in accordance with DSU

Article 3.6.

Consultations themselves are confidential in

accordance with DSU Article 4.6.

WTO members can request to join in consultations pursuant to DSU Article 4.11 or issue their own request for consultation.

In accordance with DSU Article 3.6, members may raise any point relating to MAS before the relevant Councils and Committees to which the MAS was notified.

Members may also initiate a request for consultations over a measure adopted pursuant to a MAS.

Aside from the general requirement of MAS' consistency with WTO agreements pursuant to DSU Articles 3.5 and 3.7, Article 3.5 explicitly stipulates that MAS 'shall not nullify or impair benefits accruing to any Member under those agreements'.

The three requirements in DSU Article 3.5 ensure that MAS strengthen and not undermine the WTO.

MAS:

(1) have to be consistent with the covered agreements;

(2) shall not nullify or impair benefits accruing to any Member under those agreements;

(3) shall not impede the attainment of any objective of those agreements. 
to reform the DSU. Already in 1994, the WTO Ministerial Conference called for a revision of the DSU until $1999^{140}$ and the Doha Ministerial Conference agreed upon a re-negotiation of the DSU in 2001. ${ }^{141}$

As for MAS notification, there is a consensus among the membership to reform DSU Article 3.6. A number of different WTO members submitted proposals that shared the desire to make notification more detailed and to set a time limit for notification of 60 days. ${ }^{142}$ The 2003 negotiation text under chairman Péter Balás reflected these preferences in the new Article 3.6. ${ }^{143}$ The 2011 negotiation text goes even further and limits the notification period to ten days after reaching a settlement. ${ }^{144}$ Furthermore the new text clarifies that both parties ('each party') have to notify. Hence, much progress has been made on the rules governing notification.

A more contentious issue in current negotiation is the enforceability of MAS. Early on, the EC submitted a proposal to treat a failure to implement the terms of a notified MAS as a violation of the covered agreements and to amend DSU Articles 21.5 and 22 so that a party could initiate compliance proceedings to enforce a MAS. ${ }^{145}$ According to the EC, this would make MAS more attractive and save time and resources, as a complainant would not have to restart a new procedure. ${ }^{146}$ However, the proposed changes have not been introduced in the negotiation draft. According to the recent report by the DSB Special Session Chairman

140 WTO Ministerial Conference, The Decision on the Application and Review of the Understanding on Rules and Procedures Governing the Settlement of Disputes, available at: www.wto.org/english/docs_e/ legal_e/53-ddsu.pdf.

141 Doha Ministerial Declaration, 20 November 2001, WT/MIN(01)/DEC/1, para. 30.

142 Communication from India on behalf of Cuba, Dominican Republic, Honduras, Jamaica, and Malaysia, Dispute Settlement Body - Special Session - Dispute Settlement Understanding Proposals: Legal Text, TN/DS/W/47, 11 February 2003. Proposal by Japan, Dispute Settlement Body-Special Session-Amendment of the Understanding on Rules and Procedures Governing the Settlement of Disputes, TN/DS/W/32, 22 January 2003. Proposal by Japan, Dispute Settlement Body-Special Session-Negotiations on Improvements and Clarifications of the Dispute Settlement Understanding, TN/DS/W/22, 28 October 2002. Proposals on DSU by Cuba, Honduras, India, Malaysia, Pakistan, Sri Lanka, Tanzania, and Zimbabwe, Dispute Settlement Body-Special Session-Negotiations on the Dispute Settlement Understanding, TN/DS/W/18, 7 October 2002.

143 Report by the Chairman, Ambassador Péter Balás, to the Trade Negotiations Committee, Dispute Settlement Body-Special Session, TN/DS/9, 6 June 2003.

144 Report by the Chairman, Ambassador Ronald Saborío Soto, to the Trade Negotiations Committee, Dispute Settlement Body-Special session, TN/DS/25, 21 April 2011. The new Article 3.6 reads:

'Each party [to a mutually agreed solution] with respect to a matter raised under the dispute settlement provisions of the covered agreements shall notify the detailed terms of such solution to the DSB and relevant Councils and Committees. The notification shall be made in writing and submitted within 10 days after reaching the solution. Any Member may raise any point relating to the solution in the DSB and the relevant Councils and Committees.'

145 Communication from the European Communities, Dispute Settlement Body-Special Session-Contribution of the European Communities and its Member States to the Improvement of the WTO Dispute Settlement, TN/DS/W/1, 13 March 2002.

146 Ibid., $7,8$. 
Ronald Saborío Soto, disagreement still persists over that issue. ${ }^{147}$ While some scholars have made a compelling case for such reform, ${ }^{148}$ the need for additional enforcement capacity may be overrated (see also section 6). First, given that only in a minority of cases non-implementation was alleged, the majority of MAS seem to be complied with. Second, members are free to include other enforcement mechanisms in their MAS such as arbitration pursuant to DSU Article 25. Third, unless they waived their right of standing, members can always bring a new case of non-compliance against the initial measure if they are unsatisfied with the compliance of a MAS. Finally, the conclusion of more and more MoUs is shifting the compliance debate to interim-settlements where more regulation and follow-up is needed. Hence, there is little added-value in including a further enforcement mechanism in the DSU for MAS.

However, if members decide to accept the EC's proposal and strengthen enforceability of MAS, they should simultaneously improve the control mechanisms of third parties to check MAS consistency. Instead of only letting members 'raise any point relating to' MAS before the relevant WTO bodies, a WTO Committee could be designated to monitor new MAS for WTO conformity on its own accord. Furthermore, it could also be clarified that compliance panels, as envisaged by the EC, should not only enforce but also check a MAS for consistency with DSU Articles 3.5, 3.6, and 3.7.149

Two issues raised in this study, however, do not currently feature on the DSU reform agenda. First, the WTO would benefit from a more clearly defined objective concept of amicable settlements. This could take the form of a MAS definition in the DSU. But even more limited efforts could prove fruitful. Currently, researchers and states alike have to actively look beyond regular Article 3.6 notifications to find potential settlements 'hidden' in DSB minutes or Article 21.3(b) submissions. Instead the WTO Secretariat in its efforts for more transparency could, in coordination with the WTO membership, compile a publicly accessible list of all known amicable WTO settlements whether formally notified or not.

Second, the on-going DSU reform turns a blind eye to the issue of interimsettlements which are steadily growing in numbers. Legal security and transparency would be greatly enhanced, if the provisions of the DSU made a clear distinction between MAS as final settlements and interim-settlements such as MoUs introducing new disciplines on the latter. As part of a two-stage procedure, parties could

147 Report by the Chairman, Ambassador Ronald Saborío Soto, supra n. 144, paras. 104-107.

148 Ernst-Ulrich Petersmann (2002), 'Additional Negotiation Proposals on Improvements and Clarifications of the DSU, in Ernst-Ulrich Petersmann (ed.), Preparing the Doha Development Round: Improvements and Clarifications of the WTO Dispute Settlement Understanding, Florence: EUI/RSC, pp. 125-139, at 131. Joost Pauwelyn (2003), 'The Limits of Litigation: Americanization and Negotiation in the Settlement of WTO', Ohio State Journal on Dispute Resolution, 19(1): 121-140, at 134. Shoyer, 'The First Three Years of WTO Dispute Settlement', supra n. 99, at 287-290.

149 See also Pauwelyn, 'The Limits of Litigation', supra n. 148, at 134. 
be required to notify and report continuously on the progress made in implementing interim-settlements until the moment that a final MAS is reached. ${ }^{150}$ Such a regime would strengthen and streamline the settlement practice for the disputing parties. At the same time, it would bring interim-settlements that currently escape regulation into the ordinary DSU structures allowing other members and the interested public to follow their progress towards a final settlement more closely.

In conclusion, the DSU at it stands today is already relatively well equipped to deal with many of the balancing considerations arising out of MAS, aligning disputants' flexibility needs and 'instant dispute' resolution with collective stakes and 'systemic goals'. Together with the refinements already tabled and those newly proposed in this study, the DSU can further enhance legal security and predictability in the law governing MAS and foster amicable solutions that strengthen the multilateral trading system.

150 A possible DSU Article 3.6bis could read:

'Any agreement reached with a view to conclude a mutually agreed solution shall be subject to the requirements of Article 3.6. The dispute shall remain on the DSB's agenda until a mutually agreed solution is notified.' 